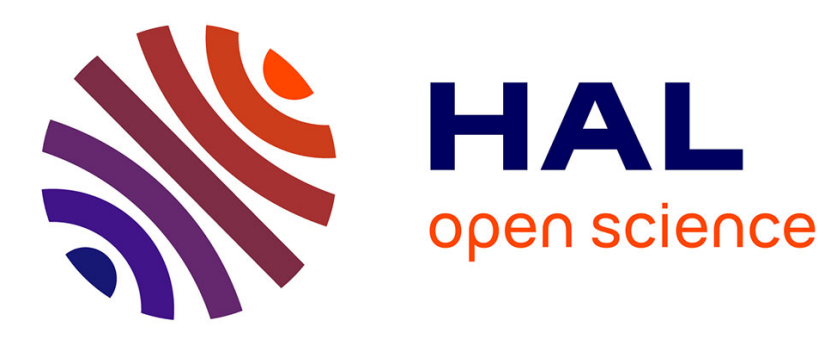

\title{
Remittances matter: Longitudinal evidence from Albania
}

Laetitia Duval, François-Charles Wolff

\section{To cite this version:}

Laetitia Duval, François-Charles Wolff. Remittances matter: Longitudinal evidence from Albania. 2009. hal-00421234

\section{HAL Id: hal-00421234 \\ https://hal.science/hal-00421234}

Preprint submitted on 1 Oct 2009

HAL is a multi-disciplinary open access archive for the deposit and dissemination of scientific research documents, whether they are published or not. The documents may come from teaching and research institutions in France or abroad, or from public or private research centers.
L'archive ouverte pluridisciplinaire HAL, est destinée au dépôt et à la diffusion de documents scientifiques de niveau recherche, publiés ou non, émanant des établissements d'enseignement et de recherche français ou étrangers, des laboratoires publics ou privés. 
EA 4272

\title{
Remittances matter: Longitudinal evidence from Albania
}

\author{
Laetitia DUVAL $\left(^{*}\right)$ \\ François-Charles Wolff $\left({ }^{* *}\right)$
}

$2009 / 20$

$\left.{ }^{*}\right)$ LEMNA, Université de Nantes

$\left.{ }^{* *}\right)$ LEMNA, Université de Nantes; CNAV and INED, France

Septembre 2009

INSTITUT d'ECONOMIE et de MANAGEMENT de NANTES - IAE
Laboratoire d'Economie et de Management Nantes-Atlantique Université de Nantes

Chemin de la Censive du Tertre - BP 52231

44322 Nantes cedex 3 - France

www.univ-nantes.fr/iemn-iae/recherche

UNIVERSITÉ DE NANTES

Tél. +33 (0)2 40141719 - Fax +33 (0)2 40141749 


\title{
Remittances matter: Longitudinal evidence from Albania ${ }^{\#}$
}

\author{
Laetitia Duval * $\quad$ François-Charles Wolff $^{* *}$
}

September 2009

\begin{abstract}
Using the LSMS panel data collected by the World Bank in Albania from 2002 to 2004, this paper focuses on the determinants and financial implication of remittances sent by family members and adult children living abroad. Our econometric analysis draws on random and fixed effects discrete choice models. We find that the proportion of households receiving remittances is large. These transfers are negatively correlated with both the donor's and the recipient's level of education. Finally, remittances have a positive impact on economic indicators like satisfaction with current situation, adequateness of food consumption and number of affordable expenditures.
\end{abstract}

Classification JEL: I32, 015

Keywords: Remittances, Albania, subjective financial situation

\footnotetext{
${ }^{\text {\#}}$ We would like to thank Roger Clarke, the editor, Frédéric Docquier, Claudia Senik, El Mouhoub Mouhoud and seminar participants during the GDN-SEE Workshop held at the Vienna Institute for International Economic Studies for their helpful comments and remarks on a previous draft. Any remaining errors are ours.

* Corresponding author. LEMNA, Université de Nantes, France. E-mail: duval.laetitia@yahoo.com

${ }^{* *}$ LEMNA, Université de Nantes; CNAV and INED, Paris, France. E-mail: francois.wolff@univ-nantes.fr www.sc-eco.univ-nantes.fr/ fcwolff
} 


\section{Introduction}

According to the World Bank (2008), remittances are rapidly increasing over time, from $\$ 119$ billion in 1997 to $\$ 370$ billion in 2007. The proportion of remittances to developing countries is also increasing, from 60\% in 1997 (\$71 billion) to 75\% in 2007 (\$280 billion). Eastern Europe and Central Asia have benefited from larger remittances, $\$ 50$ billion in 2007, which is five times higher than the 1997 level. Interestingly, three countries of Eastern Europe are among the main recipients of remittances as percentage of gross domestic product (GDP): Albania, Bosnia and Herzegovina, and Moldova ${ }^{1}$.

While remittances are an important source of external financing for developing countries, they also provide significant resources for many recipient households ${ }^{2}$. For instance, Edwards and Ureta (2003) find that $15 \%$ of the Salvadorian households benefit from remittances, which represent about $43 \%$ of their incomes. Given their magnitude, and in fine their potential effects on development, economists have paid a growing attention to these transfers from abroad during the last twenty years. From a microeconomic perspective, previous studies on remittances have focused on the two following aspects.

On the one hand, some papers have attempted to understand why migrants remit to their family members left in the origin country. From a theoretical viewpoint, several motives have been suggested to explain these transfers (Rapoport and Docquier, 2006). A first motive deals with altruism, meaning that migrants care of those left behind. According to the second motivation, there is an exchange when the migrants remit for services provided by the recipients (Lucas and Stark, 1985). A third motive stems from familial interactions. This may take the form of an insurance contract that protects its members against shocks (Rosenzweig, 1988), but remittances may also be a loan repayment for the costs of migrant's education and emigration (Poirine, 1997).

On the other hand, some studies have focused on the implications of remittances on the recipients. A first issue deals with poverty alleviation. Adams (2004) finds that remittances have a significant impact on reducing the depth and severity of poverty in Guatemala ${ }^{3}$. A

\footnotetext{
${ }^{1}$ In nominal terms, the main recipients of remittances are India, Mexico and China. As a share of GDP, the main recipients are smaller countries like Albania, where remittances amount to more than $15 \%$ of GDP (in 2006). A significant part of remittances being sent through informal channels, the true amount of remittances is in fact much larger. The World Bank (2008) suggests that remittances sent through informal channels could add at least $50 \%$ to the official estimate.

${ }^{2}$ Remittances are more than twice as large as official aid and they exceed for some countries the volume of foreign direct investments (Ratha, 2005). For instance, remittances to Albania are estimated to \$1359 million in 2006 , while foreign direct investments are estimated to $\$ 325$ million.

${ }^{3}$ Results are less clear concerning the effect of remittances on income inequality. See for instance Adams (1992) and Taylor and Wyatt (1996).
} 
second issue is about how these transfers from abroad are spent or invested. Hildebrandt and McKenzie (2005) find that children living in recipient households have a lower mortality rate in Mexico. Edwards and Ureta (2003) find a positive impact of remittances on school attendance and retention in El Salvador. Remittances facilitate housing investments in Nigeria (Osili, 2004) and generate investments among small enterprises in Mexico (Woodruff and Zenteno, 2007). Finally, remittances are associated with a decrease in the labor force participation of women and men in Nicaragua (Funkhouser, 1992) . $^{4}$

The purpose of our contribution is to bring evidence on the implications of these transfers on the financial situation of transfer recipients living in Albania. Unlike countries of Latin America for instance, studies on remittances in Eastern countries remain scarce. Specifically, we draw on a rich data set collected by the World Bank among households over the period 2002-2004 to document the pattern of remittances in that country. The Albanian Living Standard Measurement Study (LSMS hereafter) is a longitudinal survey, meaning that we are able to control for unobserved heterogeneity through the use of household fixed effects. Another feature of the data is that in 2003, we know some characteristics of respondents and all their adult children, living either in Albania or abroad, and information on remittances (if any) from the latter category of children. Finally, there are subjective questions on the financial situation of the households.

For various reasons, the case of Albania is a very relevant one. On the one hand, the country is an area of particularly high international migration flows. According to the World Bank (2008), the stock of emigrants expressed as percentage of population is estimated to $27.5 \%$. On the other hand, Albania is characterized by an uncertainty in terms of income due to the transformation from the communist system towards a market economy. On a priori grounds, additional sources of income like remittances should thus have a strong impact on households.

We proceed in the following way in our empirical analysis. First, we describe the pattern of remittances in Albania. We show that the bulk of these transfers is made by adult children and that remittances are mainly related to food and basic necessities. We then focus on the determinants of these transfers and study whether they are influenced by individual characteristics. Using random and fixed effects discrete choice models, we find that the probability of receiving a transfer is not really higher when the recipient is in a poor situation. Finally, we evidence a significantly positive effect of these transfers on the financial situation

\footnotetext{
${ }^{4}$ Yang (2008) highlights a depressing effect of remittances on labor supply of children in the Philippines.
} 
of the recipient household.

The remainder of this paper is organized as follows. In Section 2, we present the LSMS data. The pattern of remittances in Albania is described in Section 3. We investigate their determinants in Section 4 and examine their implications on the financial situation of the recipient households in Section 5. Finally, Section 6 concludes.

\section{The LSMS Albanian data}

We use data from the LSMS project conducted in Albania at the beginning of the 2000's. The survey was carried out by the Albanian Institute of Statistics with the technical and financial assistance of the World Bank ${ }^{5}$. The LSMS project is an international effort supported by the World Bank in order to improve the quality of household survey data for policy needs. It is thus a crucial tool in measuring poverty in developing countries.

Let us first describe the context of Albania along with the challenges during the transition. Following the collapse of communism, Albania has pursued strong reforms towards a market economy. After a period of erratic growth in the early 1990's, linked to transition and several political crises, the GDP has significantly increased $(5.7 \%$ on average between 2000 and 2005). However, living standards in Albania remain among the lowest in Europe and about one quarter of the Albanian population lives below the poverty line. The human development index is lower than the average level observed in Eastern Europe, respectively 0.784 instead of 0.802 .

However, the proximity of attracting neighboring countries like Italy and Greece offers some opportunities of migration. Albania has recently emerged from a repressive political regime, at a time when travelling to foreign countries was totally restricted. Albania is now the largest emigration country in Europe (as a portion of the population) ${ }^{6}$. According to the OECD database on immigrants and expatriates, around $64.4 \%$ of Albanian migrants live in Greece and $25.4 \%$ in Italy $^{7}$. As shown in Korovilas (1999), all these migrants have an important role in supporting the Albanian economy since a large proportion of their incomes is transferred back home. Remittances are larger than other aggregates like exports, foreign direct investments or official aid. Furthermore, these transfers from abroad are increasing over time, from \$152 million in 1992 to \$1071 million in 2007.

\footnotetext{
${ }^{5}$ For further information on the Albanian LSMS survey, see the documentation of the World Bank available online: http://www.worldbank.org/lsms/index.htm.

${ }^{6}$ According to the World Bank (2008), there are 860485 international migrants. By comparison, the Albanian population comprises 3 million of inhabitants.

Conversely, only $6.3 \%$ of Albanian migrants live in the United States.
} 
In this study, we use the LSMS Albanian longitudinal data and consider three waves covering the period from 2002 to 2004 . The 2002 LSMS survey is a nationally representative sample of households living in Albania. The sample was designed to be representative of urban and rural areas and was composed of 3600 households. Four questionnaires were used in order to collect information: a household questionnaire, a diary recording household consumption, a community questionnaire and a price questionnaire. The focus in the second and third waves was only on the first instrument, i.e. the household questionnaire ${ }^{8}$. The sample sizes in 2003 and 2004 were approximately half of the original sample.

Let us now describe the main questions of interest for our study. Concerning remittances, information in the first wave (2002) is available in the transfers and social assistance module. The definition of the transfer variables includes both remittances and transfers from family members living in Albania. Nevertheless, as we know where the potential donors live (in Albania, Greece, Italy, United States, etc), we can isolate transfers from abroad. We also know the relationship between the donors and the head of the household (spouse, children, siblings, etc). The amount of these inflows, either in cash or in-kind, are reported in the questionnaire and there is also some information on the main reasons explaining why the donor has provided this assistance (for instance for food and basic necessities, investment, medical expenses, etc).

When turning to the second wave (2003), the corresponding information is available in the migration module, which is more detailed than in the first wave. In particular, there is an additional section on adult children living by their own, either in Albania or in a foreign country. For each adult child living abroad, we know whether the head of the household has received a remittance from this specific child and the corresponding amount (if any). The questionnaire also includes the main uses of the transfer. We have also more detailed questions on remittances received from specific family members living abroad like siblings, nephews, uncles, etc. Finally, in 2004, the information is very similar to the one found in 2002 since there is a module on remittances and other sources of income. We know the relationship between each person remitting to the household and the head, the location of the donor and the amount given. Unfortunately, there is no information in 2004 on the main uses of remittances.

To assess the implications of remittances on recipient households, we use a set of

\footnotetext{
${ }^{8}$ The diary for household consumption, the community questionnaire and the price questionnaire were not repeated in 2003 and 2004. Significant efforts have been made to reduce the length and complexity of the 2002 LSMS round. The second and third waves of the panel are a reduced version of the 2002 LSMS survey with some additional elements required for the panel, like details of people moving into and out of the household.
} 
questions related to the current financial situation that are included in the subjective module of the Albanian LSMS survey. The first one is about subjective satisfaction: "How satisfied are you with your current financial situation?". Possible answers are "fully satisfied", "rather satisfied", "less than satisfied", and "not at all satisfied". The second question is about the current level of food consumption: "Would you consider the current level of food consumption of your family as...?". Possible answers are "more than adequate", "just adequate", "less than adequate". The last indicator is related to the existence of liquidity constraints: "If you wanted to, could your household afford to...?" . Answers are given for each of the following items: "have friends or family for a drink or meal at least once a month", "pay for a week's annual holiday away from home", "replace worn out furniture", "buy new rather than second hand clothes", "eat meat, chicken or fish at least every second day", "keep your house adequately warm". We then construct an ordered indicator measuring the number of items that the household is able to fulfill. The range of this indicator is from 0 to 6 , a low value meaning that the household is severely constrained.

We construct two different samples from the LSMS data. The first one is a merged sample using the 2002, 2003 and 2004 waves, each household being tracked over time. We then get an unbalanced sample of 5539 observations, with respectively 1889 households in 2002, 1842 in 2003 and 1808 in 2004. The main interest of this sample is to study the receipt of transfers from all family members living outside Albania. As we have repeated information over time, we will be able to control for unobserved heterogeneity at the household level through the use of fixed effects. For these households, the survey provides detailed characteristics on their demographic and socio-economic situation, including age, marital status, number of persons in the household, education, health status, position on the labor market, religion and living in an urban area among others.

Our second sample focuses on adult children and concerns the 2003 wave. Indeed, the LSMS survey includes in 2003 a set of detailed questions on all adult children of the head, either living in Albania or living in abroad. As we have also information about their potential transfers made to the household, we choose to construct a matched sample where each child (whatever the geographic location) is counted as one observation. This means that for a head with three adult children, our sample includes three child-parent pairs. This sample includes 2396 adult children, 1056 of them living in a foreign country. The main interest of this sample is to shed light on the intra-household allocation of transfers, since it indicates who is

\footnotetext{
${ }^{9}$ This information about potential constraints is only available in the 2003 and 2004 waves.
} 
remitting among the various siblings. Also, we are able to control for the characteristics of both the parent and the child in our regressions. For each adult child, we have information about gender, age, marital status, level of education, whether they have migrated with family in foreign countries, whether they live in Albania and whether they have sent money to the household.

\section{The pattern of remittances in Albania}

We begin with a description of the pattern of remittances in Albania. The LSMS survey allows us to explore some basic questions about the characteristics of donors and recipients. Who remits? Who receives? Where do the remitting persons live? How much money is remitted? What is the main use of these remittances? In our empirical analysis, we make a difference between remittances from all persons (using the 2002-2003-2004 merged sample) and remittances from adult children (using the 2003 parent-child sample).

Let us first focus on the transfer rate. More than one household over four has benefited from remittances over the last three years, the average proportion of recipients being equal to 27.6\%. However, there are differences over time. The transfer rate is similar in 2002 and 2004 , respectively $23.3 \%$ and $24.2 \%$, but it amounts to $35.1 \%$ in 2003 . This is puzzling as there is no particular economic shock over the period, but recall that there are differences in the labeling of the questions measuring transfers in the survey. Both in 2002 and 2004, the head of the household is asked about any transfers received from other persons (and has then to say whether the transfer has been made by a child, a parent, a sibling, etc), while in 2003 there are several questions indicating the receipt of a transfer for each category of potential senders (children, siblings, uncles, etc). So, our results show that the measurement of remittances is highly sensitive to the design of the questionnaires.

As shown in Table 1, the bulk of remittances are made by adult children to the head of the household. Among all transfers made, the proportion of transfers sent by children is $62.6 \%$ in $2002,59.7 \%$ in 2003 , and $74.9 \%$ in 2004 . Remittances are also frequently made by siblings, about one transfer over four ${ }^{10}$. In Figure 1, we calculate the distribution of the total value of remittances by type of donor. Again, we find that much of the money is sent by adult children, around $53 \%$ of the total amount in 2002 and $77 \%$ in 2004 . More money is sent by siblings in 2002 (about $30 \%$ of the total value) than in 2004 (about 10\%).

\footnotetext{
${ }^{10}$ An interesting result of Table 1 is that in 2003, the proportion of transfers made by other family members is much higher than in 2002 and 2004 (respectively 10.8\% instead of $2.3 \%$ and $1.5 \%$ ). As previously discussed, this difference stems from the fact that there are more detailed questions on the other family senders in 2003.
} 


\section{Insert Figure 1 here}

We then perform the same calculations by donor's location using the 2002 and 2004 waves, the origin of the remittances being not available in 2003. We find a very similar pattern for both years. Among all transfers made, about $42 \%$ of them come from Greece, $40 \%$ from Italy, $10 \%$ from other European countries, and the rest from other countries (mainly from the United States). When considering the distribution of amounts, Figure 2 shows that Greece is the main origin of remittances to Albania in 2002 (about $40 \%$ of the total value), but Italy becomes in 2004 the first country (about $45 \%$ of the total value). We also describe in Figure 2 the origin of the total amount of remittances from adult children using the 2003 wave. More than $70 \%$ of the remittances come from Greece and Italy and $20 \%$ of these flows are sent by adult children living in other European countries.

\section{Insert Figure 2 here}

In the 2002 and 2003 questionnaires, we also know the main use of remittances by the recipient households. Nevertheless, answers have to be interpreted with caution as this is a self-reported information. In Figure 3, we first describe the proportion of transfers concerned with the different uses described in the survey. When considering all transfers (2002 wave), we find that $58 \%$ of the remittances are claimed to supply for food and basic necessities, less than $20 \%$ are related to investment, and about $15 \%$ to medical expenses.

\section{Insert Figure 3 here}

There are some differences when focusing on transfers made by non-coresident children only (2003 wave). Although most of the transfers are still related to food and basic necessities (more than 60\%), we find that there are more remittances from children related to investment. Figure 4 indicates the distribution of the total amount of remittances by use of transfer. The main result is that among adult children, remittances are much higher on average when they serve an investment purpose. They represent about $20 \%$ of all transfers made in frequency, but they amount to about $50 \%$ of all the money transferred.

\section{Insert Figure 4 here}

Finally, we describe the selected samples. In Table 1, we report the household's characteristics depending on whether they receive a transfer from abroad or not. On average, recipients are slightly older than non-recipients (53 years old instead of 50 in 2002), they live less frequently in couple, and their level of education is on average lower. For instance, 29.5\% of the recipients have not completed primary school in 2002, while the same proportion is $21.6 \%$ among non-recipients. Recipients are also less likely to have a paid work, respectively 
$55.1 \%$ instead of $63.6 \%$ in $2002^{11}$. Another result is that recipients are poorer on average. Using the 2002 wave, we find that the household's income of the recipients is $14.2 \%$ lower than that of non-recipients. Finally, we observe significant differences by religion and location. Recipients are less often Muslim and they live less frequently in an urban area.

Insert Table 1 here

We now turn to the sample of non-coresident children in 2003, described in Table 2. The proportion of children living in Albania is 55.9\% (1340/2396). There are significant differences in characteristics between children depending on their location. For instance, the proportion of daughters living in Albania is $64.2 \%$, but $63.4 \%$ of emigrant children are sons. Emigrants are much younger than children living in Albania: 52.6\% of the latter are above 35 years old, while the same proportion is only $30.2 \%$ among those who have migrated. Children living outside Albania are more educated on average ${ }^{12}$. Finally, $12 \%$ of children living in Albania have ever migrated and returned.

\section{Insert Table 2 here}

When comparing remitters and non-remitters, we find that the proportion of men is much larger in the former group than in the latter (73.9\% instead of 50.5\%). Remitters are slightly older, $43 \%$ of them between 26-35 years old compared to 35\% among non-remitters. Children sending money are more likely to have completed only primary school, while high educated children make less often remittances. Two other interesting results concern the migration profile. On the one hand, the average number of years since migration is roughly the same for the two groups of adult children (about five years). On the other hand, children who send money are less likely to live with a spouse or with their children abroad.

\section{The determinants of remittances}

\subsection{The role of the recipients' characteristics}

Let us focus on the characteristics of the households who benefit from remittances. We begin with a cross-sectional econometric analysis using the 2002 wave, as there is an accurate measure of the household's income only for that year. Let $T_{i, 02}^{*}$ be a latent variable measuring the propensity for a household $i$ to receive a transfer in 2002. This indicator $T_{i, 02}^{*}$ is expected

\footnotetext{
${ }^{11}$ Very similar results are observed in 2003 and 2004 for the educational level and job status. For instance, the proportion of heads having a job is $54.3 \%$ among recipients instead of $65.2 \%$ among non-recipients in 2004 . A difference between the 2002 and 2003/2004 waves is related to health. Both in 2003 and 2004, recipients are more likely to be in poor health than non-recipients (respectively $16.5 \%$ instead of $12.5 \%$ in 2003 , and $16.7 \%$ instead of $11.8 \%$ in 2004).

${ }^{12}$ The proportion of children having completed more than primary education is equal to $51.2 \%$ among those who live outside, but $41.8 \%$ among those who live in Albania.
} 
to depend on a set of characteristics $X_{i, 02}$, a vector of coefficients $\beta_{02}$ and a residual $\varepsilon_{i, 02}$, so that $T_{i, 02}^{*}=\beta^{\prime} X_{i, 02}+\varepsilon_{i, 02}$. By definition, we do not observe the latent transfer variable $T_{i, 02}^{*}$, but the data provide information on the observed counterpart $T_{i, 02}$. We have $T_{i, 02}=1$ when $T_{i, 02}^{*}>0$ and $T_{i, 02}=0$ otherwise. Assuming that the residual is normally distributed, the corresponding specification is a simple Probit model. A second dependent variable is the transfer amount, which is equal to 0 when the household does not receive a transfer, and the appropriate specification is a Tobit model.

Both the Probit and Tobit estimates for the 2002 wave are reported in Panel A of Table 3. The different covariates introduced in the regressions are related to the head and concern age, marital status, level of education, number of persons in the household, poor health, job status, household income, religion (being Muslim), and living in an urban area. It is important to note here that we are not able to control for the characteristics of the potential donors. The probability of receiving money is positively correlated with the age of the respondent. An explanation is that older respondents are more likely to have adult children living abroad, these children being the main providers of remittances in Albania.

\section{Insert Table 3 here}

Being married does not influence the probability to receive money. The coefficient is also insignificant for the number of persons. A difficulty here is that we do not know how many family members live abroad. On the one hand, remittances should increase with the number of persons living in Albania. On the other hand, when there are more people living in the household, this may indicate that few family members have migrated and this reduces the opportunity to receive some money from abroad. While the different educational dummies have a negative influence, the estimate becomes significant only for the University grade.

As shown in Table 3, the probability to be helped is lower when the donor has a paid job, although this effect is only significant at the 10 percent level. As this means that the head benefits from a regular source of resources, then this result is more consistent with altruism. A negative effect of the household's income on the transfer receipt is expected under that motive (Rapoport and Docquier, 2006). Unfortunately, this is not really the case with the LSMS data. Although we get a negative relationship between the transfer value and the recipient's income, the corresponding estimate is absolutely not significant at conventional levels. So, it cannot be claimed that the donors strongly account for the recipient's economic situation before sending money. Another result against an altruistic motive is that the transfer is reduced when the head 
is in poor health ${ }^{13}$. Finally, Muslim respondents are less likely to benefit from remittances, while there is no difference between households living in rural and urban locations.

As we have repeated information on both transfers and household's characteristics (2002, 2003, 2004), we are able to control for unobserved heterogeneity at the household level. The model we estimate may be expressed as $T_{i, t}^{*}=\beta^{\prime} X_{i, t}+\delta_{i}+\varepsilon_{i, t}$, where $i$ and $t$ as subscripts indicate respectively the respondent and the year of survey, and $\delta_{i}$ is an unobserved individual effect. These perturbations are supposed to be normally distributed, with mean 0 and variance $\sigma_{\delta}^{2}$, and the error terms $\varepsilon_{i, t}$ are also supposed to be normally distributed with unitary variance. Under the assumption that the covariates are uncorrelated with the individual effects, the corresponding model is a random effects Probit model which is estimated using Gaussian quadrature techniques (Butler and Moffitt, 1982).

As shown in Panel B of Table 3 (column 1), the probability of receipt is again an increasing function of the head's age. Transfers are also more likely when the head lives in couple and when there are few persons living in the household. These covariates were not significant when considering the 2002 wave only. At the same time, being in poor health and having a job are no longer significant in the regression. In fact, the main result of interest is that high educated respondents are less likely to receive remittances. A difficulty here is that we are not able to include the household's income in the list of covariates, which prevents us from testing the relevance of the altruistic model. Also, transfers are less likely to be received by respondents living in urban area.

As a final step, we assume that the household unobserved effects are correlated with the different covariates. The appropriate specification is the fixed effects Logit model described in Chamberlain (1980). The sample is then restricted to respondents who have received a transfer during at least one year, but not over the whole period. All the characteristics of the respondent invariant over time (like education or religion) are dropped from the regression. The sample is then restricted to 705 respondents. As shown in Panel B of Table 3 (column 3), we find that the number of persons living in the household has a negative effect on the probability of being helped, while the other covariates are not significant. This casts doubt on an altruistic motive as the donor should take into account the situation of the recipient (meaning that remittances should depend on health and job status for instance).

\footnotetext{
${ }^{13}$ We get very similar effects of the different covariates both on the probability to receive a transfer and on the amount of remittances.
} 


\subsection{Who is sending remittances among children?}

In the above regressions, we were only able to control for the characteristics of the recipients of the transfers as we had no description of the different donors in the LSMS survey. This is undoubtedly a shortcoming as the transfer is expected to depend on both the donor and the recipient's characteristics under either altruism or exchange ${ }^{14}$. In what follows, we restrict our attention to the different transfers made by adult children to their parents in 2003 using the matched parent-child sample.

As there are several children in many families, we are now able to control for unobserved heterogeneity at the family level. We denote respectively by $j$ and $i$ as subscripts the child and the parent. Drawing on a latent variable specification, the probability for a child to send money is expressed as $T_{j, i}^{*}=\beta^{\prime} X_{j, i}+\theta_{i}+\varepsilon_{j, i}$, where $\theta_{i}$ is an unobserved family effect and $\varepsilon_{j, i}$ a random perturbation. The family fixed effect is expected to pick up all the factors related to the parents that have previously influenced the migration of the children. We use the following covariates for the children: sex, age, birth order, having a spouse or children living abroad, level of education and duration of the migration. The selected parental characteristics are age, marital situation, number of adult children living outside the household, number of persons in the household, level of education, being in poor health, having a paid work, religion and rural-urban status.

Assuming that the family fixed effects are uncorrelated with the explanatory variables, the appropriate specification is a random effects Probit model. The sample comprises 1056 parent-child pairs (585 families) and the corresponding estimates are in column 1 of Table 4. Daughters living abroad are less likely to remit than sons (at the 1 percent level). The probability of making a transfer is an increasing function of the donor's age. Younger children are presumably less able to send money because of a less secure situation in the destination country. This would be consistent with the fact that the likelihood of remitting is also increasing with the duration of migration. Another interpretation of this result is that Albanian migrants keep a strong attachment to their origin country.

\section{Insert Table 4 here}

An important covariate in our context is education. According to our estimates, high educated children (especially when they have studied at university) are less likely to send money to their parents. According to the loan repayment motive, migrants are considered as

\footnotetext{
${ }^{14}$ For instance, controlling only for the recipient's level of education without having information on the donor's socio-economic status is likely to lead to biased results. See the further discussion in Altonji et al. (1997).
} 
borrowers and they have to send money to reimburse their family who has supported emigration costs and investment in human capital. A positive correlation between remittances and the migrant's education level is thus expected, meaning that the negative effect of the donor's education evidenced in Albania allows us to rule out that motivation. A last finding is the lower probability of remittances for the children who live either with their spouse or with their children in the destination country. Such migrants are clearly less likely to return to the origin country and they have also fewer resources to send to their parents.

A striking feature is that the characteristics of the parents hardly affect the probability of receiving money. However, with respect to the results discussed before in Table 3, it should be noted that we now only focus on the transfers made by adult children to their parents ${ }^{15}$. According to Table 4, we find that parents living in an urban area are less likely to receive remittances. As there is no measure of the respondent's resources in 2003, we control for the level of household income in 2002 in the regression. While the corresponding coefficient is not significant with the Probit specification, we evidence a negative correlation between the amount of transfers and the recipient's income when estimating a random effects Tobit model (column 2, Table 4).

That less well-off parents receive more transfers from abroad is a priori more consistent with altruism than with exchange. Nevertheless, if children really take into account the well-being of their parents, then they should send more transfers to their parents when the latter do not have a job or are in poor health. This is clearly not the case according to the LSMS data, which suggests that children are not so strongly altruistic. At the same time, because they live in a distant country, it could be that children have an imperfect knowledge of the economic situation of their parents.

As a final step, using a fixed effects Logit model, we estimate the probability that a child sends money among families in which at least one adult child living abroad, but not all, makes a transfer. The number of observations is reduced to 359 (118 families). Parental characteristics are no longer included as they do not vary among the children of a given family. The corresponding estimates are reported in column 3 of Table 4 . With respect to the random effects specification, we find very similar results although a few covariates are no longer significant ${ }^{16}$. The probability of sending money is higher for daughters than for sons. It

\footnotetext{
15 The use of matched samples remains scarce in the literature on remittances, an interesting exception being Osili (2007). As we introduce both the characteristics of the child and the parent in the regression, we have also estimated the random effects Probit model with the parental variables only. Again, we do not find that the characteristics of the parent influence the receipt of a transfer.

${ }^{16}$ But recall that the number of observations is strongly reduced when estimating the conditional Logit model.
} 
is reduced when the migrant child lives with children abroad, and it is increasing with time spent in the destination country. Also, there is still a negative correlation (albeit hardly significant) between remittances and education.

To summarize, our different results from panel data and parent-child matched samples do not provide unambiguous evidence in favor of a specific motive of remittances in Albania. This undoubtedly stems from several difficulties pointed out in the remittances literature (Rapoport and Docquier, 2006). On the one hand, it is uneasy to discriminate between competing theories of remittances as different models lead to similar predictions. On the other hand, there may be some heterogeneity in the transfer motives within the population. Some migrants may send transfers because of altruism, while the transfers from other migrants may be part of an exchange. Furthermore, a given migrant may have several motives depending on who is the recipient ${ }^{17}$.

\section{The effect of remittances on the recipient's financial situation}

We now focus on the impact of these transfers on the recipients. Our analysis is based on three indicators related to subjective financial satisfaction, adequateness of the current level of food consumption, and expenditures the household can afford to. We describe in Figure 5 the relationship between these indicators and the receipt of a transfer.

We first consider all the transfers received by the households over the 2002-2004 period (Panel A). The proportion of respondents being not satisfied at all amounts to 39\% among the non-recipients, while it is equal to $32 \%$ among those who have benefited from remittances. At the same time, those who have received a transfer are more likely to be satisfied (17\% instead of 13\%). In a similar way, recipients claim more often that their level of consumption is just or more than adequate than non-recipients (64\% instead of $56 \%$ ). Finally, those who receive remittances are less likely to be liquidity constrained.

\section{Insert Figure 5 here}

Very similar results hold when focusing on the transfers made by adult children using the 2003 wave (Panel B, Figure 5). For the various indicators, we find that respondents are in a better financial position when receiving remittances and the improvement of their situation is significant. For instance, $36 \%$ of the respondents who are not financially helped by their migrant children claim that their current level of food consumption is less than adequate, while the proportion is $27 \%$ among those who receive remittances. Albeit preliminary, these

\footnotetext{
${ }^{17}$ For instance, a migrant may send remittances to poor parents because of altruism and to siblings as part of an exchange if the latter supervise the various investments made by the migrant in the origin country.
} 
findings suggest that transfers provide a large contribution to the recipients' situation. We further investigate this issue using an econometric analysis.

\subsection{Transfers from all migrants}

We focus here on remittances sent by all migrants to the respondents and study the determinants of the financial situation using the longitudinal data over the period 2002-2004. To explain the various outcomes, we introduce the following characteristics related to the respondent: gender, age, marital status, number of persons in the household, level of education, health status, having a job, religion, and rural-urban status. We also introduce in the regression a dummy variable which is equal to 1 when the respondent receives a transfer from abroad and to 0 otherwise. As our different indicators of financial situation are given by ordered variables, we turn to random effects ordered Probit models as we have repeated information over time for each respondent.

The different results are reported in Panel A of Table 5. For the three outcomes, we find a better financial situation for respondents living in couple, having achieved high education, being in good health and having a job. All these results are in accordance with expectations. For instance, a high level of education is associated to a higher level of permanent income, meaning that respondents should have more resources to devote to their own consumption. While the number of persons in the household is negatively correlated with both the satisfaction with financial situation and the adequateness of the current level of food consumption, it does not significantly affect the number of expenditures the household can afford to. A similar pattern is observed when the respondent lives in an urban area ${ }^{18}$.

\section{Insert Table 5 here}

The most interesting result is that the receipt of remittances makes respondents more satisfied about their current financial situation. The coefficient associated to the transfer dummy is positive and significant at the 1 percent level. A similar result holds for the adequateness of the current level of food consumption. However, there is no significant correlation between the receipt of remittances and the number of expenditures that the household can afford to, although the coefficient remains positive. That the receipt of remittances improves the satisfaction with current financial situation and consumption is consistent with our previous results according to which migrants are more likely to support households in a poor economic situation and needing financial support.

\footnotetext{
${ }^{18}$ This result may be more surprising as poverty is essentially rural in Albania. An explanation is that in rural areas, households may rely on subsistence agricultural activities to fulfill their own needs.
} 
As the household unobserved effects may be correlated with the characteristics of the respondents, we have also estimated a fixed effect ordered Probit model. A difficulty here is that there is no direct approach to estimate such model. We thus proceed in the following way. Assuming that the ordered financial indicator $F$ may take values from 1 to $K$, we estimate a set of conditional Logit models by grouping adjacent outcomes for the dependent variables $F^{k}$ (with $k=1, \ldots K$ ) such that $F^{k}=1$ if $F^{k}>k$ and $F^{k}=0$ otherwise. For each $F^{k}$, we get a consistent estimate $\beta^{k}$ of $\beta$ using the fixed effects Logit estimator.

We then rely on a classical minimum distance estimator to get a restricted estimator for $\beta$ from the various $\beta^{k}$. Specifically, we solve $\min _{\delta}(\hat{\vartheta}-H \beta)^{\prime} \hat{V}^{-1}(\hat{\vartheta}-H \beta)$, where $\hat{V}$ is a weighting positive definite matrix and $\vartheta$ is the unrestricted vector $\vartheta=\left(\beta^{1}, \ldots, \beta^{K-1}{ }^{\prime}\right)^{\prime}$. The mapping from $\vartheta$ to $\beta$ is linear, with $\vartheta=H \beta$. The solution is $\hat{\beta}=\left(H^{\prime} \hat{V}^{-1} H\right)^{-1}\left(H^{\prime} \hat{V}^{-1} \hat{\vartheta}\right)$ and the asymptotic covariance matrix is given by $V(\hat{\beta})=\left(H^{\prime} \hat{V}^{-1} H\right)^{-1}$. Results from the fixed effects ordered Probit model are in Panel B of Table $5^{19}$.

In what follows, we restrict our attention to the role of remittances. For the three financial outcomes under consideration (current income satisfaction, consumption satisfaction, and possible expenditures), we get a positive coefficient for the transfer dummy. So, our findings suggest that remittances significantly improve the financial situation of the recipients. Nevertheless, as shown in Dimova and Wolff (2008), a difficulty here is that remittances are unlikely to be exogenous. Indeed, the migrant's decision to transfer resources to the family living in Albania is itself expected to depend on the recipient's economic status, meaning that the coefficient associated to the remittances dummy in the various ordered regressions is likely to be biased under the exogeneity assumption.

When using the longitudinal sample, we are only able to control for the respondent's characteristics in the ordered regressions. It thus seems difficult, and even unlikely, to rely on an instrumental variable approach to correct the endogeneity bias. As the receipt of remittances is like a treatment (recipients being the treated group and non-recipients the control group), we consider an alternative strategy based on the propensity score matching estimator as this method is expected to reduce the bias in the estimation of treatment effects with observational data sets (Becker and Ichino, 2002). For that purpose, the comparison of outcomes between recipients and non-recipients has to be performed using treated and control subjects who are as similar as possible. The pre-treatment characteristics of each respondent

\footnotetext{
${ }^{19}$ Again, the education variable is no longer in the regression as it does not vary over time.
} 
are summarized into a single-index variable, the so-called propensity score. The extent to which this bias is reduced depends on the quality of the control variables on which the propensity score is computed and the matching performed ${ }^{20}$.

We proceed in the following way with the LSMS data. We first estimate a Probit model to explain the probability for each respondent to receive at least one transfer from abroad over the period 2002-2004, i.e. the treatment $T$. The list of covariates $X$ introduced in the regression includes age (with a quadratic profile), marital status, number of persons in the household, level of education (four dummies), being in poor health, work status, religion and urban-rural status. We then compute the propensity score $\operatorname{Pr}(T=1 \mid X)=E(T \mid X)$. Finally, we estimate the causal effect of the receipt of transfers on the respondent's financial situation using a Kernel matching estimator (Heckman et al., 1998). The average effect of the treatment on the treated is given by $A T T=E\left(F_{1}-F_{0} \mid T=1\right), F_{1}$ and $F_{0}$ being the outcomes in the situations of respectively treatment (receipt of remittances) and no treatment ${ }^{21}$.

We report in Table 6 the results of the propensity score analysis for the various financial outcomes. Let us focus on the matching estimates when all remittances over the period 2002-2004 are taken into account. Under the exogeneity assumption (unmatched estimates), we find that the difference in satisfaction with financial situation between the treated and the control groups is equal to 0.105 , but the ATT estimate amounts to 0.131 and is significant at the 1 percent level. Similar results are observed for the adequateness of the level of food consumption (the unmachted difference is 0.084 while the ATT estimate is 0.102 ), and for the number of expenditures the household can afford to. The unmatched estimator is equal to 0.062 and not statistically significant, but it is more than three times higher $(0.221)$ with the propensity score matching analysis and significant at the 1 percent level. Remittances have then a causal, positive effect on the financial situation of the recipients.

Insert Table 6 here

\subsection{The case of remittances sent by adult children}

We now extend our investigations to the case of remittances sent by adult children in 2003. As a preliminary step, we investigate the household characteristics that influence our

\footnotetext{
${ }^{20}$ There is no bias when the exposure to treatment can be considered to be purely random among respondents who have the same value of the propensity score. However, this does not eliminate the bias generated by unobservable factors.

${ }^{21}$ When implementing the propensity score matching analysis, we check the relevance of the balancing property, i.e. the means of each explanatory variable should not differ between treated and control units after the matching. Results from the various Probit regressions estimated to compute the propensity score are available upon request.
} 
three financial indicators (current income satisfaction, consumption satisfaction, and possible expenditures) using standard ordered Probit models. The different explanatory variables are gender, age, marital status, number of persons in the household, level of education, being in poor health, having a job, religion, and rural-urban status. We also include the exogenous receipt of remittances in the various regressions.

\section{Insert Table 7 here}

As shown in Panel A of Table 7, satisfaction with current financial situation is higher when the respondent is high educated, has a job and is in good health. Similar findings holds for the adequateness of food consumption and expenditures the household can afford to. Our main result is the positive effect of the remittances dummy, which is significant at the 1 percent level for the three outcomes. Those who benefit from transfers sent by their adult children living abroad are more likely to be in a better off position. Note that this finding was expected, given the previous positive effect found for all transfers from abroad along with the crucial role of children in supporting the Albanian households.

To control for the potential selection of poorer households in the program (receipt of remittances), we first apply the propensity score matching analysis on the parent-child sample. When considering the unmatched sample, the differences between the treated and the control groups are respectively equal to 0.109 for satisfaction with current financial situation, 0.086 for adequateness of food consumption and 0.160 for number of potential expenditures (see Table 6). Once properly matched, the corresponding values for the ATT estimate are respectively equal to $0.122,0.106$ and 0.338 , all significant at the 1 percent level $^{22}$. So, the positive impact of remittances on living standard remains once we control for selection due to observable characteristics.

To assess the robustness of our findings, we then turn to an IV strategy to account for selection both on observables and unobservables. The idea is as follows. On the one hand, the household's economic situation is expected to depend on the respondent's characteristics and on the transfer variable. On the other hand, the (endogenous) transfer variable will be affected by both the respondent and the donor's characteristics. This suggests that the child's characteristics can be used as instrumental variables as they will directly impact the decision to send money to the parents, while they should not directly affect the household situation

\footnotetext{
${ }^{22}$ Note that we get very similar results when considering either all the transfers from abroad or only transfers from adult siblings. For instance, the ATT estimate is equal to 0.122 when using the 2003 parent-child sample, while it amounts to 0.131 when considering the longitudinal sample with all transfers. The difference is larger when considering the number of expenditures the household can afford to, the ATT estimate being higher with remittances from adult children.
} 
(but they should have an indirect effect through the transfer).

Given the available information in the LSMS data, the different instruments pertaining to the children are gender, age, birth order, living with a spouse, living with children, education and years spent abroad. Nevertheless, it could be argued that some of these variables are themselves influenced by the permanent economic situation of the parents. For instance, the educational level of the child is expected to be strongly correlated with the parental level of education, and high educated parents should be less concerned with financial problems. A simple way to deal with this issue consists in excluding from the list of instruments the characteristics of the children that are more deeply influenced by the parental background, in particular education and years spent abroad. Characteristics of the children like gender, age or birth order should clearly not be correlated with the parental current economic situation.

We proceed in the following way when turning to the data. As a preliminary step, we rely on IV linear models, meaning that we treat both the dependent and endogenous variables as continuous ${ }^{23}$. Under exogeneity, the transfer variable is equal to 0.144 in the financial satisfaction equation (with a t-test of 3.69). This coefficient is equal to $0.453(t=3.12)$ when the transfer is expressed as a function of all the children's characteristics and to $0.466(\mathrm{t}=2.95)$ when both education and duration of migration are excluded from the list of instruments (as these covariates could be correlated with the parent's situation). In both cases, we perform an overidentification test of our instruments. The values of the Sargan statistic are respectively equal to 1.96 and 1.46 (with respectively 8 and 4 degrees of freedom), suggesting that our exclusion restrictions are appropriate.

We find very similar results for adequateness of food consumption, the joint null hypothesis that the instruments are valid being again satisfied. The coefficient of the transfer variable is equal to 0.095 under exogeneity $(t=3.18)$ and it is about 0.3 once endogeneity is taken into account (with both sets of instruments). The results are a little bit less convincing with our indicator pertaining to number of expenditures the household can afford to. The coefficient associated to remittances is equal to $0.330(\mathrm{t}=3.75)$ under exogeneity and is twice higher $(0.702$, with $\mathrm{t}=2.02)$ when the child's gender, age and rank within the sibship are used as instruments. However, the coefficient is not significant $(0.446$, with $t=1.40)$ when the child's education and duration of migration are added as control variables.

It should be noted that the above estimates have to be seen as approximations since the

\footnotetext{
${ }^{23}$ As the endogenous transfer variable is binary, we choose not to report these estimates for the sake of place. All the IV linear estimates are available upon request.
} 
endogenous transfer variable is binary and the three dependent variables are ordered. We have thus estimated simultaneous, recursive models comprising one ordered Probit equation related to the economic outcome of the household and one Probit equation related to the receipt of remittances. The crucial issue here is that we assume a bivariate normal distribution for the residuals of each equation. The corresponding log-likelihood function includes terms that are bivariate normally distributed and the model is estimating by a full information maximum likelihood method.

As shown in Panel B of Table 7, we again find a positive impact of the transfer variable on the various economic indicators under consideration ${ }^{24}$. Both for satisfaction with current situation and adequateness of food consumption, the endogenous transfer estimate from the recursive model is about twice higher than under the exogeneity assumption. Conversely, the transfer coefficient in the number of affordable expenditures equation does not really change when estimating the simultaneous model. In all equations, the receipt of remittances is significant at the 1 percent level. So, our different findings using selection techniques both on observables and unobservables appear robust. They show that in Albania, remittances from adult children have a causal effect on the economic situation of their recipients. That the receipt of transfers improves the adequateness of food consumption or the number of affordable expenditures confirms that remittances are mostly related to the most basic needs of the households living in Albania.

\section{Conclusion}

The purpose of this paper was to bring evidence on the pattern of remittances in Albania. For that purpose, we have used the longitudinal data collected over the period 20022004 by the World Bank. A particular feature of the data set is that we were able to construct a matched sample using the 2003 wave, with characteristics on both the adult children and their parents living in Albania. We rely on random and fixed effects discrete choice models to study both the determinants of remittances sent by family members and adult children living abroad and their implications on the living standard of the recipients.

Our main conclusions are as follows. First, the proportion of households living in Albania and receiving remittances is large (more than 20\%) and these transfers are mainly devoted to basic needs. Secondly, while transfers are negatively correlated with both the

\footnotetext{
${ }^{24}$ In our presentation, we only focus on the determinants of the household economic situation. Detailed results of the recursive models (included estimates related to the transfer receipt) are available upon request. Note that we get very similar results when the set of instruments includes all the characteristics of the children or when the child's education and duration of migration are excluded.
} 
donor's and the recipient's level of education, remittances do not really depend on the current situation of the recipient. Finally, transfers from abroad have a positive impact on economic indicators like satisfaction with current situation, adequateness of food consumption and number of affordable expenditures. 


\section{References}

Adams R.H., (1992), "The Impact of Migration and Remittances on Inequality in Rural Pakistan", Pakistan Development Review, vol. 31, pp. 1189-1203.

Adams R.H., (2004), "Remittances and Poverty in Guatemala", World Bank Policy Research Working Paper, $\mathrm{n}^{\circ} 3418$.

Altonji J.G., Hayashi F., Kotlikoff L.J., (1997), "Parental Altruism and Inter Vivos Transfers: Theory and Evidence", Journal of Political Economy, vol. 105, pp. 1121-1166.

Becker S., Ichino A., (2002), "Estimation of Average Treatment Effects Based on Propensity Scores”, Stata Journal, vol. 2, pp. 358-377.

Butler J.S., Moffitt R., (1982), “A Computationally Efficient Quadrature Procedure for the One Factor Multinomial Probit Model”, Econometrica, vol. 50, pp. 761-764.

Chamberlain G., (1980), "Analysis of Covariance with Qualitative Data", Review of Economic Studies, vol. 47, pp. 225-238.

Dimova R., Wolff F.C., (2008), "Are Private Transfers Poverty and Inequality Reducing? Household Level Evidence from Bulgaria”, Journal of Comparative Economics, vol. 36, pp. 584-598.

Edwards A.C., Ureta M.A., (2003), "International Migration, Remittances, and Schooling: Evidence from El Salvador", Journal of Development Economics, vol. 72, pp. 429-461.

Funkhouser E., (1992), "Migration from Nicaragua: some Recent Evidence", World Development, vol. 20, pp. 1209-1218.

Heckman J., Ichimura H., Smith J., Todd P., (1998), "Characterizing Selection Bias Using Experimental Data”, Econometrica, vol. 66, pp. 1017-1098.

Hildebrandt N., McKenzie D., (2005), "The Effects of Migration on Child Health in Mexico", Economia, vol. 6, pp. 257-289.

Korovilas J., (1999), "The Albanian Economy in Transition: the Role of Remittances and Pyramid Investment Schemes", Post-Communist Economies, vol. 11, pp. 399-415.

Lucas R.E.B., Stark O., (1985), "Motivation to remit: Evidence from Botswana", Journal of Political Economy, vol. 93, pp. 901-918.

Osili U.O., (2004), "Migrants and Housing Investments: Theory and Evidence from Nigeria", Economic Development and Cultural Change, vol. 52, pp. 821-849.

Osili U.O., (2007), "Remittances and Savings from International Migration: Theory and Evidence using a Matched Sample”, Journal of Development Economics, vol. 83, pp. 446465.

Poirine B., (1997), "A Theory of Remittances as an Implicit Family Loan Arrangement", World Development, vol. 25, pp. 589-611.

Rapoport H., Docquier F., (2006), "The Economics of Migrants' Remittances", in MercierYthier J., Kolm S.C., eds, Handbook on the Economics of Giving, Altruism and Reciprocity, Elsevier-North Holland, pp. 1135-1198.

Ratha D., (2005), "Workers' Remittances: an Important and Stable Source of External Development Finance", in Mainbo S., Ratha R., Remittances: Development Impact and Future Prospects, World Bank, Washington DC, pp. 19-52. 
Rosenzweig M.R., (1988), "Risk, Implicit Contracts and the Family in Rural Areas of Low Income Countries", Economic Journal, vol. 98, pp. 1148-1170.

Taylor J.E., Wyatt T.J., (1996), "The Shadow Value of Migrant Remittances, Income and Inequality in a Household-Farm Economy", Journal of Development Studies, vol. 32, pp. 899912.

Woodruff C., Zenteno R., (2007), "Migration Networks and Microenterprises in Mexico", Journal of Development Economics, vol. 82, pp. 509-528.

World Bank, (2008), The Migration and Remittances Factbook 2008, Washington DC.

Yang D., (2008), "International Migration, Remittances, and Household Investment: Evidence from Philippine Migrants' Exchange Rate Shocks”, Economic Journal, vol. 118, pp. 591-630. 
Figure 1. Distribution of the total amount of remittances, by type of donor

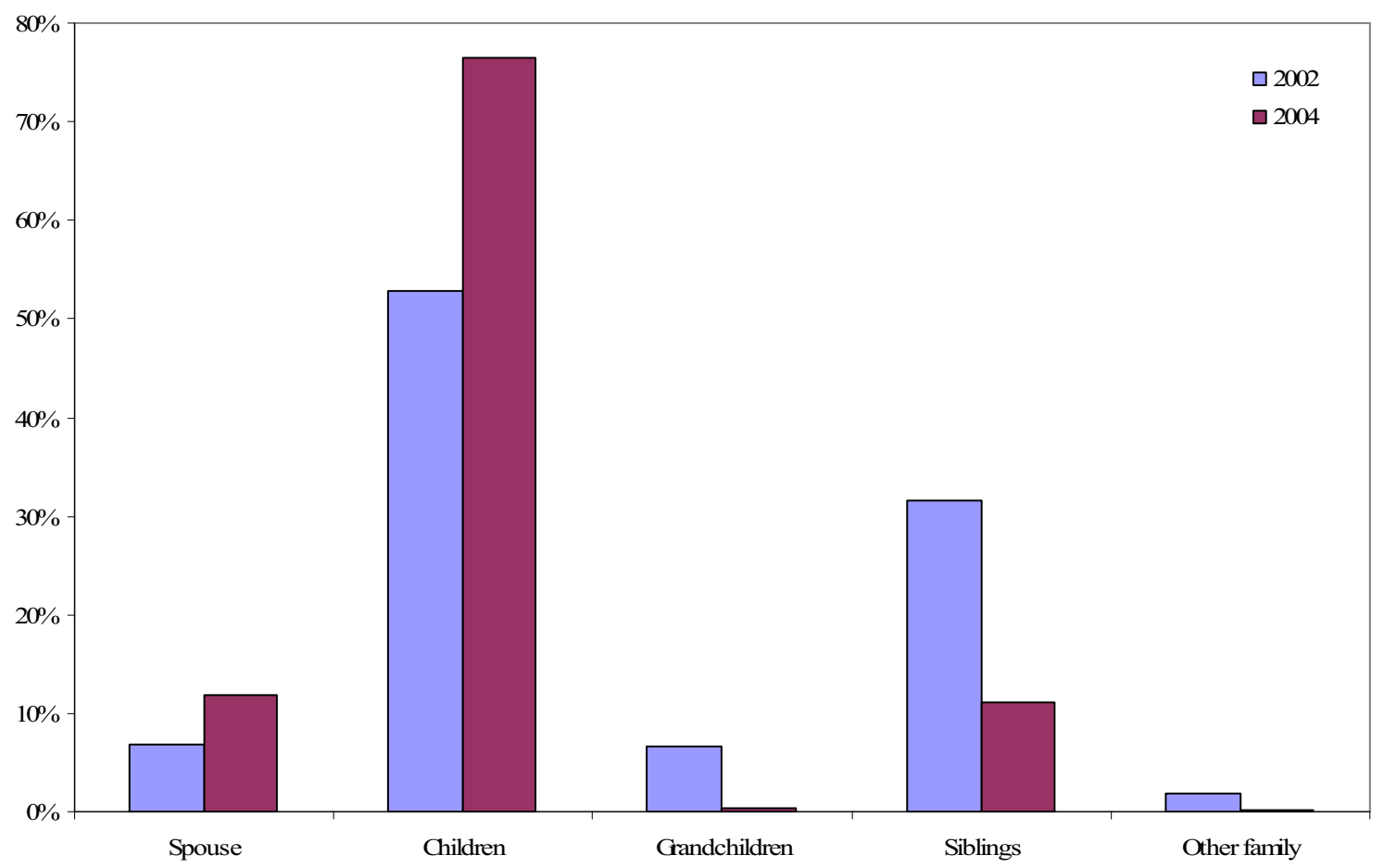

Source: LSMS Albania 2002, 2004.

Figure 2. Distribution of the total amount of remittances, by location of donor

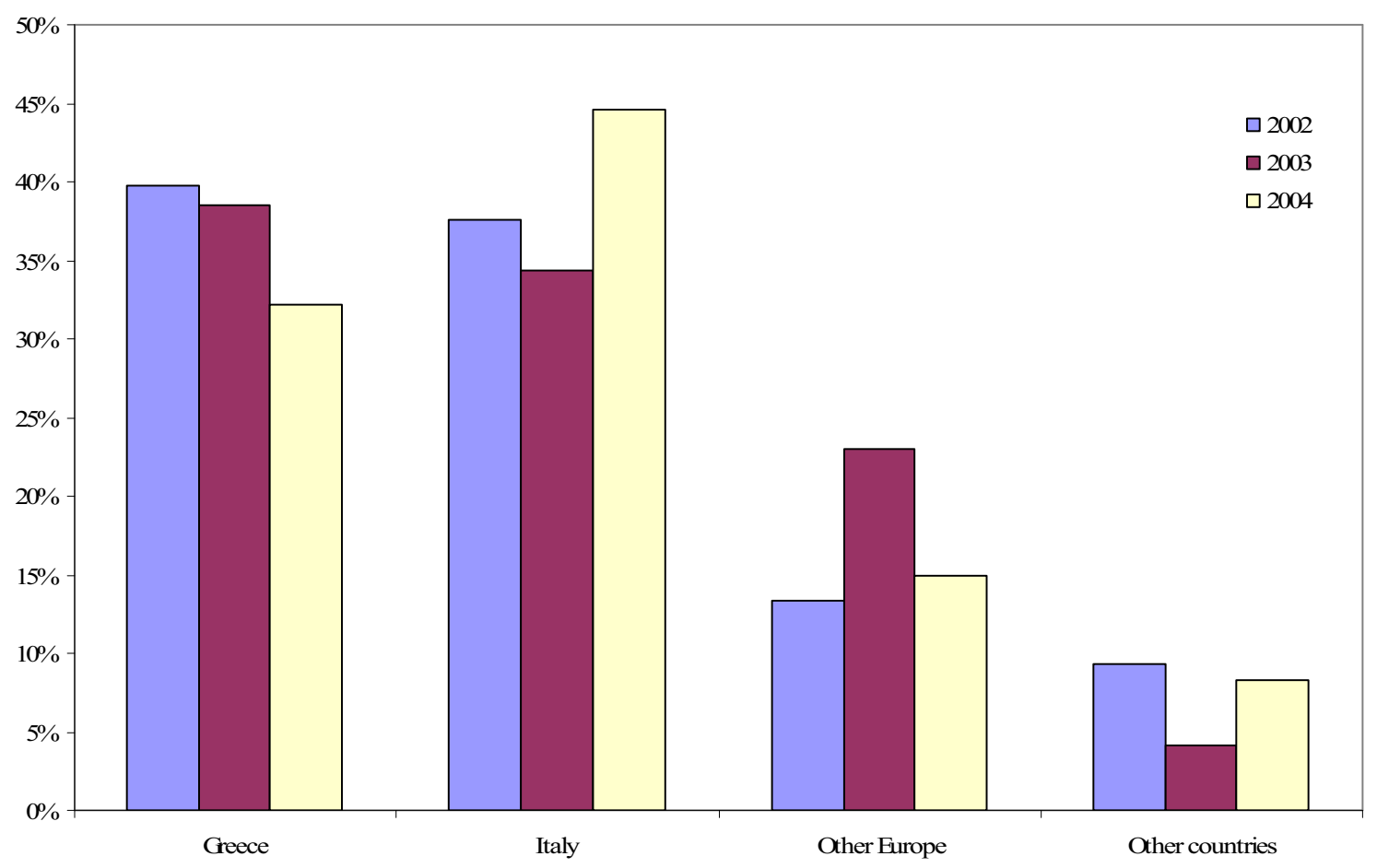

Source: LSMS Albania 2002, 2003, 2004. 
Figure 3. Self-reported use of remittances

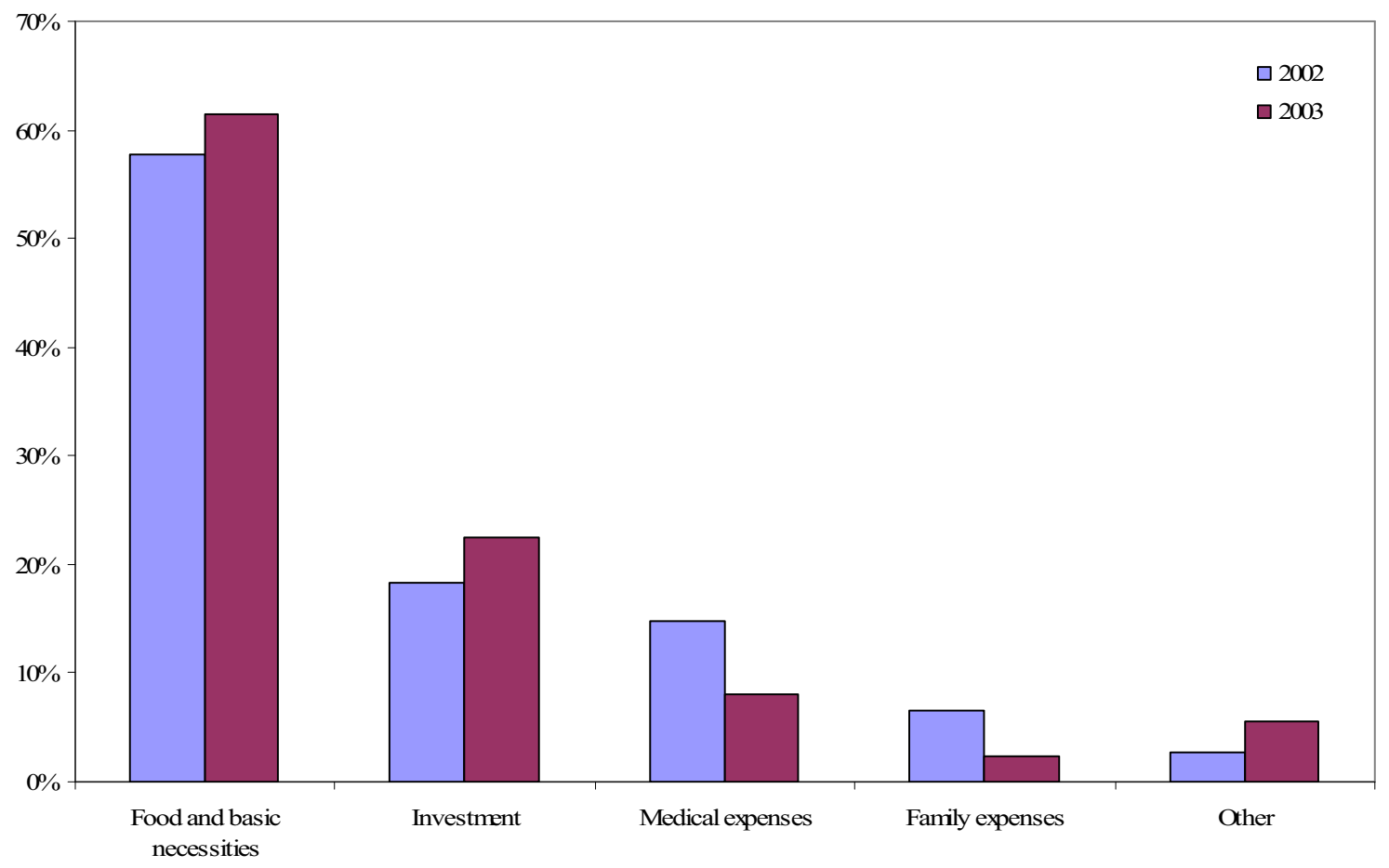

Source: LSMS Albania 2002, 2003.

Figure 4. Distribution of the total amount of remittances, by use of transfer

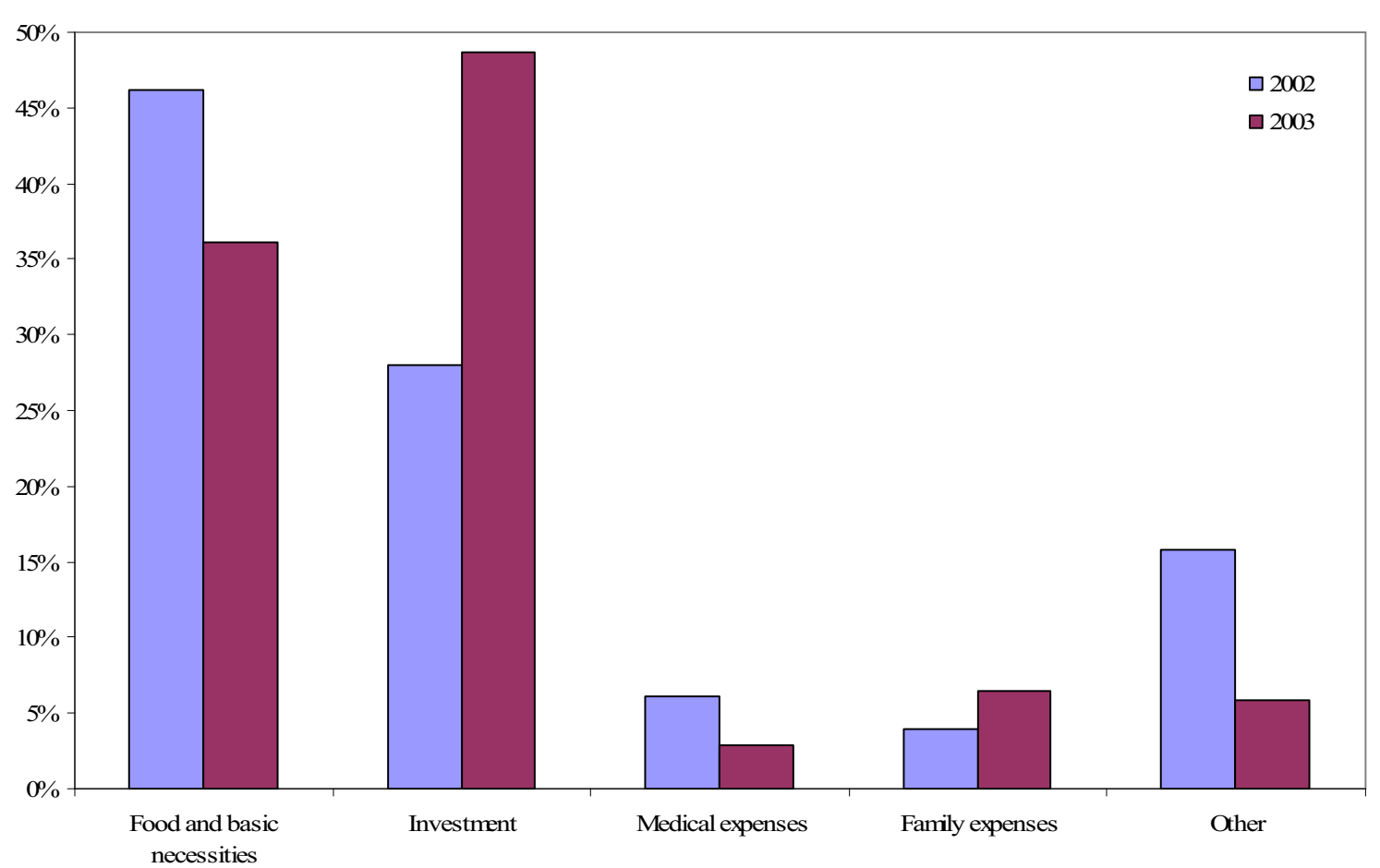

Source: LSMS Albania 2002, 2003. 
Figure 5. Receipt of remittances and financial situation

A. All remittances $(2002,2003,2004)$

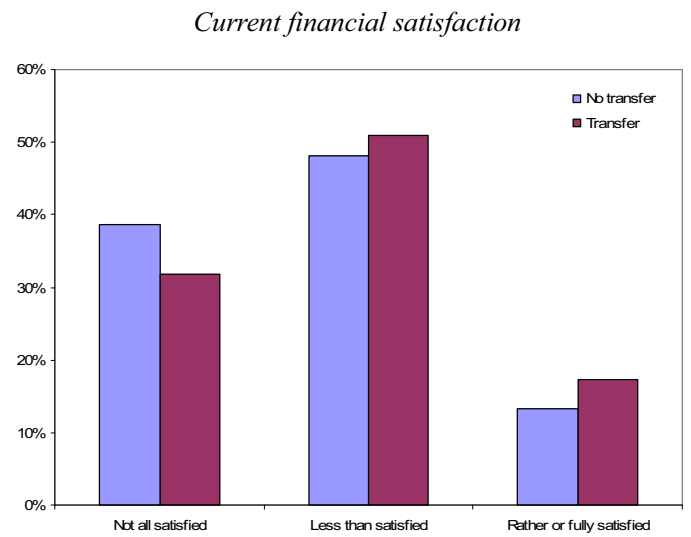

Adequate level of food consumption

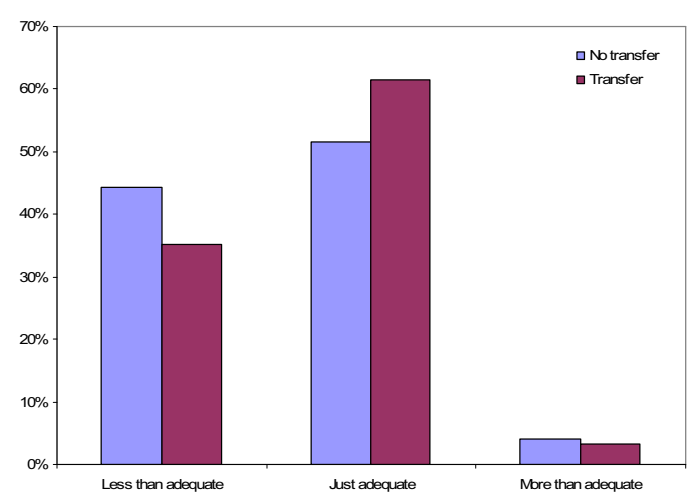

Number of expenditures the household can afford to

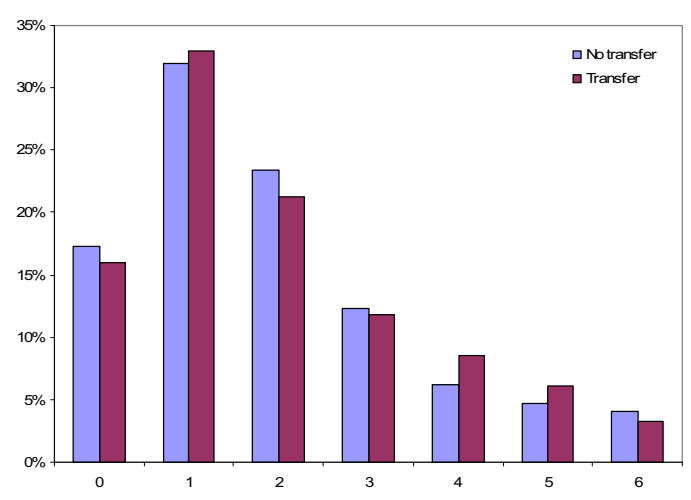

Source: LSMS Albania 2002, 2003, 2004.
B. Remittances from adult children (2003)

Current financial satisfaction

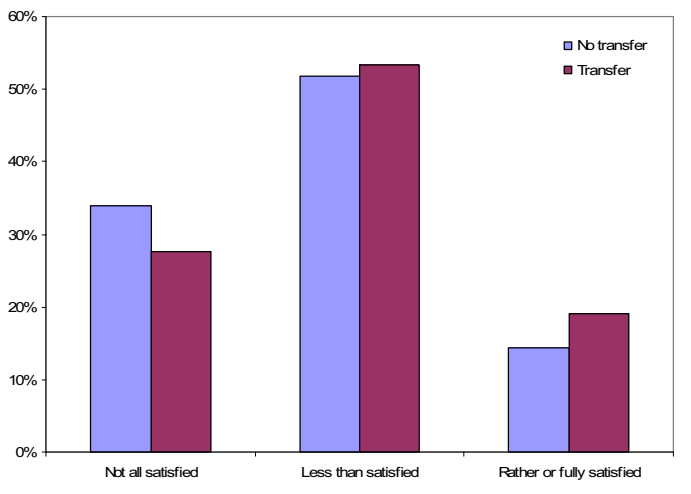

Adequate level of food consumption

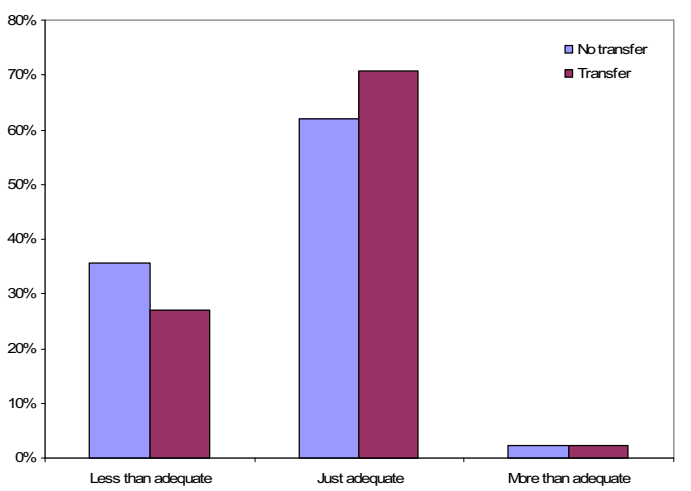

Number of expenditures the household can afford to

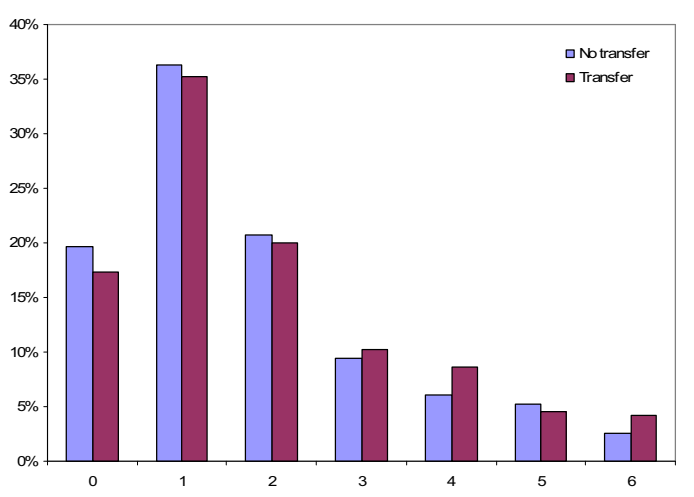


Table 1. Description of the samples

\begin{tabular}{|c|c|c|c|c|c|c|c|c|}
\hline \multirow{2}{*}{\multicolumn{2}{|c|}{ Variables }} & \multicolumn{2}{|c|}{2002} & \multicolumn{2}{|c|}{2003} & \multicolumn{2}{|c|}{2004} & \multirow[t]{2}{*}{ All } \\
\hline & & No transfer & Transfer & No transfer & Transfer & No transfer & Transfer & \\
\hline \multicolumn{9}{|c|}{ Household's characteristics } \\
\hline Head's age & & 49.902 & 53.045 & 50.078 & 54.490 & 51.548 & 55.927 & 51.619 \\
\hline Head's in coupl & & 0.865 & 0.830 & 0.842 & 0.836 & 0.828 & 0.799 & 0.840 \\
\hline Number of pers & in the household & 4.549 & 4.442 & 4.489 & 3.853 & 4.565 & 3.710 & 4.383 \\
\hline \multirow[t]{5}{*}{ Education } & Incomplete primary & 0.216 & 0.295 & 0.199 & 0.300 & 0.208 & 0.310 & 0.234 \\
\hline & Complete primary & 0.365 & 0.381 & 0.383 & 0.352 & 0.369 & 0.386 & 0.371 \\
\hline & Secondary school & 0.126 & 0.104 & 0.123 & 0.118 & 0.127 & 0.110 & 0.122 \\
\hline & Vocational & 0.178 & 0.150 & 0.180 & 0.141 & 0.175 & 0.139 & 0.168 \\
\hline & University & 0.115 & 0.070 & 0.116 & 0.088 & 0.121 & 0.055 & 0.105 \\
\hline \multicolumn{2}{|c|}{ Head in poor health } & 0.140 & 0.145 & 0.125 & 0.165 & 0.118 & 0.167 & 0.137 \\
\hline \multicolumn{2}{|c|}{ Head has a paid work } & 0.636 & 0.551 & 0.642 & 0.610 & 0.652 & 0.543 & 0.624 \\
\hline \multicolumn{2}{|c|}{ Household income in $2002(\log )$} & 9.529 & 9.387 & n.a. & n.a. & n.a. & n.a. & n.a. \\
\hline \multicolumn{2}{|l|}{ Muslim } & 0.776 & 0.705 & 0.784 & 0.725 & 0.774 & 0.735 & 0.762 \\
\hline \multicolumn{2}{|l|}{ Urban area } & 0.517 & 0.483 & 0.531 & 0.460 & 0.532 & 0.427 & 0.507 \\
\hline \multicolumn{9}{|l|}{ Remittances } \\
\hline \multicolumn{2}{|c|}{ Mean value of remittances } & 0.0 & 177200 & 0.0 & n.a & 0.0 & 112400 & \\
\hline \multicolumn{2}{|c|}{ Median value of remittances } & 0.0 & 100000 & 0.0 & n.a. & 0.0 & 80000 & \\
\hline \multirow[t]{5}{*}{ Donor } & Spouse & - & 4.9 & - & n.a. & - & 7.6 & - \\
\hline & Children & - & 62.6 & - & 59.7 & - & 74.9 & - \\
\hline & Grandchildren & - & 5.8 & - & 2.3 & - & 1.2 & - \\
\hline & Siblings & - & 24.4 & - & 27.3 & - & 14.9 & - \\
\hline & Other family & - & 2.3 & - & 10.8 & - & 1.5 & - \\
\hline \multirow[t]{4}{*}{ Origin country } & Greece & - & 42.7 & - & n.a. & - & 41.9 & - \\
\hline & Italy & - & 40.0 & - & n.a. & - & 39.2 & - \\
\hline & Other Europe & - & 9.6 & - & n.a. & - & 12.7 & - \\
\hline & Other countries & - & 7.7 & - & n.a. & - & 6.1 & - \\
\hline \multicolumn{2}{|c|}{ Number of observations } & 1448 & 441 & 1183 & 659 & 1370 & 438 & 5539 \\
\hline \multicolumn{2}{|c|}{ Proportion of donors } & \multicolumn{2}{|c|}{0.233} & \multicolumn{2}{|c|}{0.351} & \multicolumn{2}{|c|}{0.242} & 0.276 \\
\hline
\end{tabular}

Source: LSMS Albania 2002, 2003, 2004.

Note: n.a. means that the information is not available. 
Table 2. Description of the 2003 sample of non-coresident children

\begin{tabular}{|c|c|c|c|c|c|}
\hline \multirow{2}{*}{\multicolumn{2}{|c|}{ Variables }} & \multirow{2}{*}{$\begin{array}{c}\text { Children living in } \\
\text { Albania }\end{array}$} & \multicolumn{3}{|c|}{ Children living outside Albania } \\
\hline & & & No remittances & Remittances & All \\
\hline \multicolumn{6}{|c|}{\begin{tabular}{|l|} 
Child's characteristics \\
\end{tabular}} \\
\hline & Male & 35.8 & 50.5 & 73.9 & 63.4 \\
\hline & Female & 64.2 & 49.5 & 26.1 & 36.6 \\
\hline \multirow[t]{4}{*}{ Age } & Less than 26 & 12.8 & 32.7 & 28.8 & 30.6 \\
\hline & $26-35$ & 34.6 & 35.0 & 42.7 & 39.2 \\
\hline & $36-45$ & 32.2 & 21.8 & 21.1 & 21.4 \\
\hline & More than 45 & 20.4 & 10.5 & 7.4 & 8.8 \\
\hline \multirow{4}{*}{ Education } & Primary school & 58.2 & 42.1 & 54.2 & 48.8 \\
\hline & Secondary school & 20.3 & 30.6 & 25.7 & 27.9 \\
\hline & Vocational & 12.2 & 13.8 & 14.0 & 13.9 \\
\hline & University & 9.3 & 13.4 & 6.0 & 9.4 \\
\hline \multirow[t]{5}{*}{ Country } & Albania & 100.0 & 0.0 & 0.0 & 0.0 \\
\hline & Greece & 0.0 & 40.0 & 44.0 & 42.2 \\
\hline & Italy & 0.0 & 36.5 & 35.2 & 35.8 \\
\hline & Other Europe & 0.0 & 16.4 & 15.2 & 15.7 \\
\hline & Other countries & 0.0 & 7.1 & 5.5 & 6.3 \\
\hline \multicolumn{2}{|c|}{ Ever migrated and returned $(\%)$} & 12.0 & - & - & - \\
\hline \multicolumn{2}{|c|}{ Age when leaving parental home } & 23.2 & 23.3 & 23.6 & 23.4 \\
\hline \multicolumn{2}{|c|}{ Number of years since moving abroad } & - & 5.0 & 5.4 & 5.2 \\
\hline \multicolumn{2}{|c|}{ Lives with a spouse abroad (\%) } & 0.0 & 76.3 & 60.1 & 67.4 \\
\hline \multicolumn{2}{|c|}{ Lives with children abroad (\%) } & 0.0 & 62.7 & 49.6 & 55.5 \\
\hline \multicolumn{6}{|c|}{ Remittances } \\
\hline \multicolumn{2}{|l|}{ Donor $(\%)$} & - & 0.0 & 100.0 & 54.8 \\
\hline \multicolumn{2}{|c|}{ Mean value of remittances } & - & 0.0 & 131500 & 72100 \\
\hline \multicolumn{2}{|c|}{ Median value of remittances } & - & 0.0 & 50000 & 10000 \\
\hline \multicolumn{2}{|c|}{ Number of observations } & 1340 & 477 & 579 & 1056 \\
\hline
\end{tabular}

Source: LSMS Albania 2003. 
Table 3. Determinants of remittances A. Wave 2002

\begin{tabular}{|c|c|c|c|c|}
\hline Variables & \multicolumn{2}{|c|}{$\begin{array}{c}(1) \\
\text { Probit model }\end{array}$} & \multicolumn{2}{|c|}{$\begin{array}{c}\text { (2) } \\
\text { Tobit model }\end{array}$} \\
\hline Constant & $\begin{array}{c}\text { coef } \\
-0.430\end{array}$ & $\begin{array}{l}\text { t-test (abs.) } \\
(1.51)\end{array}$ & $\begin{array}{c}\text { coef } \\
-6.647\end{array}$ & $\begin{array}{l}\text { t-test (abs.) } \\
(1.58)\end{array}$ \\
\hline \multicolumn{5}{|l|}{ Household's characteristics } \\
\hline Head's age & $0.008 * * *$ & $(2.70)$ & $0.114 * * *$ & $(2.73)$ \\
\hline Head's in couple & -0.025 & $(0.25)$ & -0.280 & $(0.20)$ \\
\hline Number of persons in the household & -0.017 & $(0.93)$ & -0.191 & $(0.71)$ \\
\hline Complete primary & -0.030 & $(0.32)$ & -0.299 & $(0.22)$ \\
\hline (Ref: Incomplete) Secondary school & -0.157 & $(1.21)$ & -1.913 & $(1.01)$ \\
\hline Vocational & -0.183 & $(1.59)$ & -2.668 & $(1.59)$ \\
\hline University & $-0.389 * * *$ & $(2.78)$ & $-5.548 * * *$ & $(2.70)$ \\
\hline Head in poor health & $-0.220 * *$ & $(2.17)$ & $-3.271 * *$ & $(2.21)$ \\
\hline Head has a paid work & $-0.133^{*}$ & (1.67) & $-2.024 *$ & $(1.74)$ \\
\hline Household income in 2002 (log) & -0.019 & $(0.91)$ & -0.279 & $(0.90)$ \\
\hline Muslim & $-0.243 * * *$ & $(3.27)$ & $-3.402 * * *$ & $(3.13)$ \\
\hline Urban area & -0.049 & $(0.65)$ & -0.907 & $(0.82)$ \\
\hline $\begin{array}{l}\text { Number of observations } \\
\text { Log likelihood }\end{array}$ & & & & \\
\hline
\end{tabular}

B. Waves 2002, 2003 and 2004

\begin{tabular}{|c|c|c|c|c|}
\hline Variables & Random eff & robit model & Fixed eff & git model \\
\hline & coef & t-test (abs.) & coef & t-test (abs.) \\
\hline Constant & $-0.630 * *$ & $(2.57)$ & & \\
\hline Household's characteristics & & & & \\
\hline Head's age & $0.013 * * *$ & $(4.46)$ & 0.026 & $(0.53)$ \\
\hline Head's in couple & $0.263 * * *$ & $(2.81)$ & 0.505 & $(1.60)$ \\
\hline Number of persons in the household & $-0.147 * * *$ & $(8.03)$ & $-0.167 * *$ & $(2.45)$ \\
\hline Education $\quad$ Complete primary & -0.109 & $(1.08)$ & & \\
\hline (Ref: Incomplete) Secondary school & -0.162 & $(1.21)$ & & \\
\hline Vocational & $-0.288 * *$ & $(2.39)$ & & \\
\hline University & $-0.597 * * *$ & $(4.18)$ & & \\
\hline Head in poor health & -0.019 & $(0.23)$ & 0.195 & $(1.10)$ \\
\hline Head has a paid work & -0.082 & $(1.17)$ & -0.089 & $(0.54)$ \\
\hline Muslim & $-0.213 * * *$ & $(2.68)$ & & \\
\hline Urban area & $-0.254 * * *$ & $(3.36)$ & & \\
\hline Number of observations & & & & \\
\hline Number of families & & & & \\
\hline Log likelihood & & & & \\
\hline
\end{tabular}

Source: LSMS Albania 2002, 2003, 2004.

Note: Significance levels are respectively $1 \%\left({ }^{* * *}\right), 5 \%\left({ }^{* *}\right)$ and $10 \%\left(\left(^{*}\right)\right.$. 
Table 4. Determinants of remittances from adult children in 2003

\begin{tabular}{|c|c|c|c|c|c|c|}
\hline Variables & \multicolumn{2}{|c|}{$\begin{array}{c}(1) \\
\text { Random effects } \\
\text { Probit model } \\
\end{array}$} & \multicolumn{2}{|c|}{$\begin{array}{c}(2) \\
\text { Random effects } \\
\text { Tobit model }\end{array}$} & \multicolumn{2}{|c|}{$\begin{array}{c}\text { (3) } \\
\text { Fixed effects } \\
\text { Logit model }\end{array}$} \\
\hline 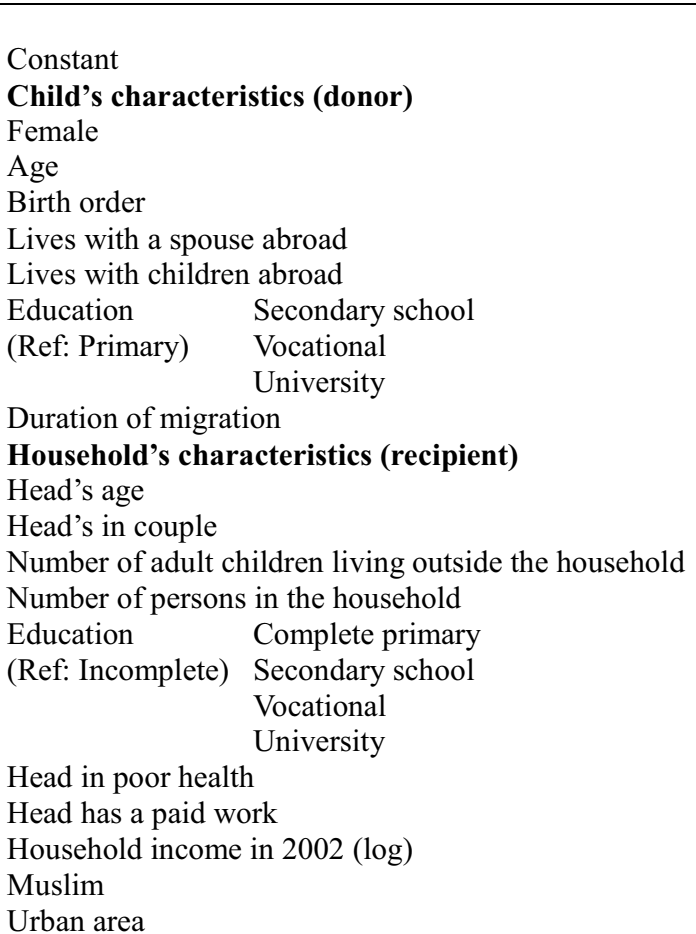 & $\begin{array}{c}-0.720^{* * *} \\
0.045^{* *} \\
0.150^{* *} \\
-0.721^{* * *} \\
-0.354^{*} \\
-0.302^{*} \\
-0.272^{* *} \\
-0.616^{* *} \\
0.070^{* *} \\
\\
-0.013 \\
0.152 \\
-0.091 \\
-0.052 \\
0.230 \\
0.519 \\
0.066 \\
-0.288 \\
0.090 \\
-0.102 \\
-0.720 \\
-0.104 \\
-0.515^{* * *}\end{array}$ & $\begin{array}{l}(0.87) \\
(0.68) \\
(1.48) \\
(1.06) \\
(1.10) \\
(1.49) \\
(0.24) \\
(0.85) \\
(0.44) \\
(0.49) \\
(1.09) \\
(0.57) \\
(2.67)\end{array}$ & $\begin{array}{c}\text { coef } \\
9.404^{* * *} \\
-3.571^{* * *} \\
0.138^{* * *} \\
0.429^{* *} \\
-2.477^{* * *} \\
-1.788^{* * *} \\
-1.217^{* *} \\
-0.754 \\
-2.251^{* * *} \\
0.305^{* * *} \\
\\
-0.064 \\
0.383 \\
-0.105 \\
-0.199 \\
0.666 \\
1.883^{*} \\
0.377 \\
-1.039 \\
0.092 \\
-0.684 \\
-3.256^{*} \\
-0.135 \\
-1.449^{* * *}\end{array}$ & $\begin{array}{l}(7.69) \\
(2.61) \\
(2.01) \\
(3.83) \\
(2.85) \\
(2.31) \\
(1.22) \\
(2.60) \\
(4.83) \\
(1.45) \\
(0.61) \\
(0.58) \\
(1.42) \\
(1.15) \\
(1.89) \\
(0.48) \\
(1.08) \\
(0.16) \\
(1.16) \\
(1.71) \\
(0.26) \\
(2.64)\end{array}$ & $\begin{array}{c}-1.780^{* * *} \\
0.128^{*} \\
0.336 \\
-0.690 \\
-1.485^{* * *} \\
-0.896^{*} \\
-0.800 \\
-1.168 \\
0.142^{* *}\end{array}$ & $\begin{array}{l}(4.72) \\
(1.84) \\
(1.55) \\
(1.35) \\
(2.80) \\
(1.87) \\
(1.58) \\
(1.42) \\
(2.46)\end{array}$ \\
\hline $\begin{array}{l}\text { Number of observations } \\
\text { Number of families } \\
\text { Log likelihood }\end{array}$ & & & & & & \\
\hline
\end{tabular}

Source: LSMS Albania 2003.

Note: Significance levels are respectively $1 \%\left({ }^{* * *}\right), 5 \%\left({ }^{* *}\right)$ and $10 \%\left(\left(^{*}\right)\right.$. 
Table 5. Determinants of financial situation, with exogenous remittances A. Random effects ordered Probit estimates

\begin{tabular}{|c|c|c|c|c|c|c|}
\hline \multirow[t]{2}{*}{ Characteristics of the head } & \multicolumn{2}{|c|}{$\begin{array}{l}(1 \mathrm{~A}) \\
\begin{array}{l}\text { Satisfaction with financial } \\
\text { situation }\end{array} \\
\end{array}$} & \multicolumn{2}{|c|}{$\begin{array}{c}\text { (2A) } \\
\begin{array}{c}\text { Adequate level of food } \\
\text { consumption }\end{array} \\
\end{array}$} & \multicolumn{2}{|c|}{$\begin{array}{c}\text { (3A) } \\
\text { Expenditures the } \\
\text { household can afford to }\end{array}$} \\
\hline & coef & t-test (abs.) & coef & t-test (abs.) & coef & t-test (abs.) \\
\hline Female & $0.198 *$ & $(1.94)$ & 0.090 & $(0.90)$ & 0.105 & $(0.87)$ \\
\hline Age & $0.026 *$ & $(1.89)$ & -0.001 & $(0.09)$ & $0.035 * *$ & $(2.12)$ \\
\hline $\operatorname{Age}^{2}(/ 100)$ & -0.007 & $(0.57)$ & 0.015 & $(1.17)$ & -0.020 & $(1.33)$ \\
\hline In couple & $0.422 * * *$ & $(4.22)$ & $0.201 * *$ & $(2.04)$ & $0.231 * *$ & $(2.01)$ \\
\hline Number of persons in the household & $-0.032 * *$ & $(2.07)$ & $-0.028 *$ & $(1.84)$ & 0.026 & $(1.35)$ \\
\hline Education $\quad$ Complete primary & $0.157^{*}$ & $(1.78)$ & $0.178 * *$ & $(2.09)$ & 0.164 & $(1.60)$ \\
\hline (Ref: Incomplete) Secondary school & $0.534 * * *$ & $(4.62)$ & $0.548 * * *$ & $(4.91)$ & $0.779 * * *$ & $(5.79)$ \\
\hline Vocational & $0.540 * * *$ & $(5.18)$ & $0.451 * * *$ & $(4.49)$ & $0.654 * * *$ & $(5.36)$ \\
\hline University & $1.183 * * *$ & $(9.73)$ & $1.143 * * *$ & $(9.73)$ & $1.635 * * *$ & $(11.49)$ \\
\hline Head in poor health & $-0.560 * * *$ & $(7.91)$ & $-0.398 * * *$ & $(5.52)$ & $-0.606 * * *$ & $(7.27)$ \\
\hline Head has a paid work & $0.407 * * *$ & $(6.92)$ & $0.348 * * *$ & $(5.81)$ & $0.276^{* * *}$ & $(3.79)$ \\
\hline Muslim & $-0.116^{*}$ & $(1.70)$ & -0.097 & $(1.48)$ & $-0.167 * *$ & $(2.11)$ \\
\hline Urban area & $-0.172 * * *$ & $(2.68)$ & $-0.216 * * *$ & $(3.47)$ & 0.095 & $(1.28)$ \\
\hline Receipt of remittances & $0.194 * * *$ & $(4.01)$ & $0.254 * * *$ & $(5.09)$ & 0.070 & $(1.26)$ \\
\hline Log likelihood & \multicolumn{2}{|c|}{-4809.8} & \multicolumn{2}{|c|}{-4038.8} & \multicolumn{2}{|c|}{-5653.3} \\
\hline
\end{tabular}

B. Fixed effects ordered Probit estimates

\begin{tabular}{|c|c|c|c|c|c|c|}
\hline \multirow[t]{2}{*}{ Characteristics of the head } & \multicolumn{2}{|c|}{$\begin{array}{c}\text { (1B) } \\
\text { Satisfaction with financial } \\
\text { situation }\end{array}$} & \multicolumn{2}{|c|}{$\begin{array}{l}\text { (2B) } \\
\begin{array}{l}\text { Adequate level of food } \\
\text { consumption }\end{array}\end{array}$} & \multicolumn{2}{|c|}{$\begin{array}{c}\text { (3B) } \\
\text { Expenditures the } \\
\text { household can afford to }\end{array}$} \\
\hline & coef & t-test (abs.) & coef & t-test (abs.) & coef & t-test (abs.) \\
\hline Age & $0.321 * *$ & $(2.36)$ & $0.539 * * *$ & $(3.62)$ & $1.849 * * *$ & $(12.56)$ \\
\hline $\operatorname{Age}^{2}(/ 100)$ & -0.145 & $(1.14)$ & -0.165 & $(1.20)$ & -0.066 & $(0.48)$ \\
\hline Number of persons in the household & $0.103 *$ & $(1.92)$ & -0.040 & $(0.67)$ & $-0.392 * * *$ & $(6.38)$ \\
\hline Head in poor health & $-0.408 * * *$ & $(2.84)$ & -0.222 & $(1.45)$ & $-0.523 * * *$ & $(3.71)$ \\
\hline Head has a paid work & $0.496 * * *$ & $(3.96)$ & $0.524 * * *$ & $(3.66)$ & $0.465 * * *$ & $(3.87)$ \\
\hline Receipt of remittances & $0.215 * *$ & $(2.20)$ & $0.528 * * *$ & $(4.70)$ & $0.853 * * *$ & $(9.70)$ \\
\hline
\end{tabular}

Source: LSMS Albania 2002, 2003, 2004.

Note: (1A), (2A) and (3A) are random effects ordered Probit estimates, (1B), (2B) and (3B) are estimates from fixed effects ordered Probit models estimated using a classical minimum distance estimator. Significance levels are respectively $1 \%\left(^{* * *}\right), 5 \%\left(^{* *}\right)$ and $10 \%$ (). 
Table 6. Propensity score estimates of the effect of remittances on financial satisfaction

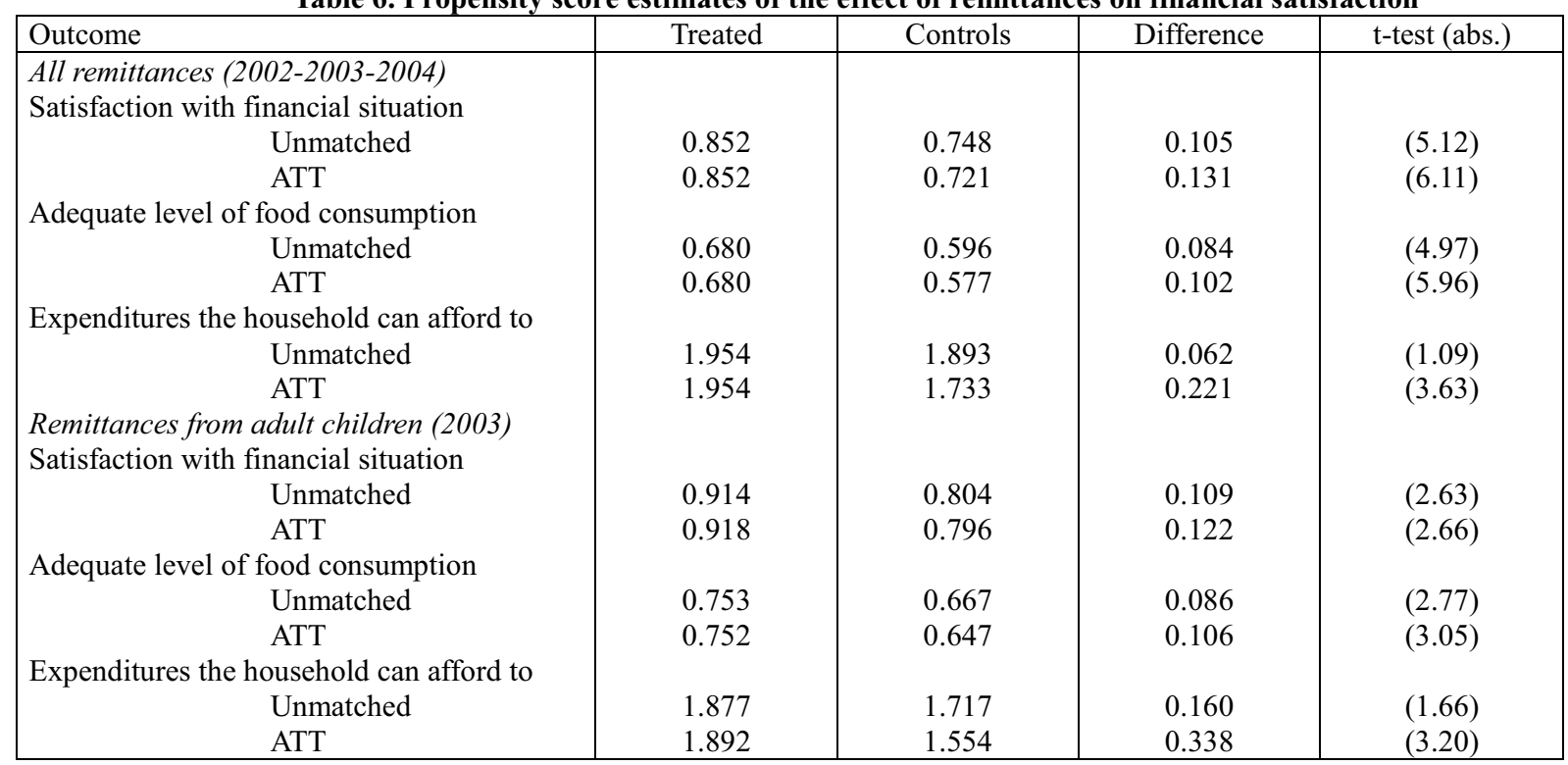

Source: LSMS Albania 2002, 2003, 2004.

Note: Significance levels are respectively $1 \%\left(\left(^{* * *}\right), 5 \%\left(^{* *}\right)\right.$ and $10 \%\left(^{*}\right)$. 
Table 7. The impact of remittances from adult children on satisfaction A. With exogenous receipt of remittances

\begin{tabular}{|c|c|c|c|c|c|c|}
\hline \multirow[t]{2}{*}{ Characteristics of the head } & \multicolumn{2}{|c|}{$\begin{array}{l}(1 \mathrm{~A}) \\
\text { Satisfaction with financial } \\
\text { situation }\end{array}$} & \multicolumn{2}{|c|}{$\begin{array}{c}(2 \mathrm{~A}) \\
\text { Adequate level of food } \\
\text { consumption }\end{array}$} & \multicolumn{2}{|c|}{$\begin{array}{c}\text { (3A) } \\
\text { Expenditures the } \\
\text { household can afford to }\end{array}$} \\
\hline & coef & t-test (abs.) & coef & t-test (abs.) & coef & t-test (abs.) \\
\hline Female & -0.076 & (0.39) & 0.107 & $(0.50)$ & 0.032 & $(0.15)$ \\
\hline Age & -0.051 & (1.37) & -0.036 & $(0.81)$ & 0.046 & $(1.26)$ \\
\hline $\operatorname{Age}^{2}(/ 100)$ & 0.039 & (1.34) & 0.036 & $(1.04)$ & -0.036 & $(1.23)$ \\
\hline In couple & 0.109 & $(0.59)$ & $0.360^{*}$ & $(1.74)$ & 0.140 & $(0.67)$ \\
\hline Number of persons in the household & -0.021 & $(0.87)$ & -0.016 & $(0.54)$ & -0.004 & $(0.18)$ \\
\hline Education $\quad$ Complete primary & 0.066 & $(0.66)$ & 0.024 & $(0.22)$ & 0.022 & $(0.24)$ \\
\hline (Ref: Incomplete) Secondary school & 0.183 & $(0.96)$ & -0.075 & $(0.39)$ & $0.469^{* * *}$ & $(2.92)$ \\
\hline Vocational & $0.216^{*}$ & $(1.91)$ & 0.219 & $(1.61)$ & 0.150 & $(1.32)$ \\
\hline University & $0.551^{* * *}$ & $(3.42)$ & $0.782^{* * *}$ & $(4.14)$ & $0.714^{* * *}$ & $(4.66)$ \\
\hline Head in poor health & $-0.392^{* * *}$ & $(4.14)$ & $-0.358^{* * *}$ & $(3.40)$ & $-0.494^{* * *}$ & $(5.16)$ \\
\hline Head has a paid work & $0.243^{* * *}$ & $(2.61)$ & $0.295^{* * *}$ & $(2.78)$ & $0.267^{* * *}$ & $(2.87)$ \\
\hline Muslim & $-0.238^{* * *}$ & $(2.89)$ & -0.132 & $(1.45)$ & -0.049 & $(0.63)$ \\
\hline Urban area & -0.021 & $(0.24)$ & -0.149 & $(1.51)$ & $0.251^{* * *}$ & $(2.92)$ \\
\hline Receipt of remittances & $0.233^{* * *}$ & $(3.13)$ & $0.266^{* * *}$ & $(3.24)$ & $0.214^{* * *}$ & $(3.17)$ \\
\hline Log likelihood & \multicolumn{2}{|c|}{-986.50} & \multicolumn{2}{|c|}{-677.34} & \multicolumn{2}{|c|}{-1634.01} \\
\hline
\end{tabular}

$B$. With endogenous receipt of remittances

\begin{tabular}{|c|c|c|c|c|c|c|}
\hline \multirow[t]{2}{*}{ Characteristics of the head } & \multicolumn{2}{|c|}{$\begin{array}{l}\text { (1B) } \\
\text { Satisfaction with financial } \\
\text { situation }\end{array}$} & \multicolumn{2}{|c|}{$\begin{array}{l}\text { (2B) } \\
\begin{array}{c}\text { Adequate level of food } \\
\text { consumption }\end{array}\end{array}$} & \multicolumn{2}{|c|}{$\begin{array}{c}\text { (3B) } \\
\text { Expenditures the } \\
\text { household can afford to }\end{array}$} \\
\hline & coef & t-test (abs.) & coef & t-test (abs.) & coef & t-test (abs.) \\
\hline Female & -0.066 & $(0.35)$ & 0.113 & $(0.53)$ & 0.031 & $(0.15)$ \\
\hline Age & -0.045 & $(1.20)$ & -0.030 & $(0.67)$ & 0.046 & $(1.26)$ \\
\hline $\operatorname{Age}^{2}(/ 100)$ & 0.034 & (1.17) & 0.031 & $(0.88)$ & -0.035 & $(1.22)$ \\
\hline In couple & 0.104 & $(0.57)$ & $0.353^{*}$ & $(1.74)$ & 0.142 & $(0.70)$ \\
\hline Number of persons in the household & -0.014 & $(0.59)$ & -0.010 & $(0.33)$ & -0.004 & $(0.18)$ \\
\hline Education $\quad$ Complete primary & 0.041 & $(0.41)$ & 0.001 & $(0.01)$ & 0.019 & $(0.21)$ \\
\hline (Ref: Incomplete) Secondary school & 0.149 & $(0.78)$ & -0.100 & $(0.53)$ & $0.468^{* * *}$ & $(2.92)$ \\
\hline Vocational & $0.224^{* *}$ & (1.99) & $0.227^{*}$ & $(1.67)$ & 0.151 & $(1.33)$ \\
\hline University & $0.573^{* * *}$ & $(3.47)$ & $0.800^{* * *}$ & $(4.20)$ & $0.715^{* * *}$ & $(4.67)$ \\
\hline Head in poor health & $-0.399^{* * *}$ & $(4.22)$ & $-0.364^{* * *}$ & $(3.48)$ & $-0.497^{* * *}$ & (5.19) \\
\hline Head has a paid work & $0.257^{\text {*** }}$ & $(2.72)$ & $0.308^{\text {*** }}$ & $(2.88)$ & $0.270^{\text {*** }}$ & $(2.92)$ \\
\hline Muslim & $-0.234^{* * *}$ & $(2.85)$ & -0.128 & (1.41) & -0.052 & $(0.74)$ \\
\hline Urban area & 0.042 & $(0.46)$ & -0.088 & $(0.78)$ & $0.252^{* * *}$ & $(2.92)$ \\
\hline Receipt of remittances & $0.569^{* *}$ & $(2.44)$ & $0.572^{* *}$ & $(2.08)$ & $0.224^{* * *}$ & $(3.11)$ \\
\hline Coefficient of correlation & -0.228 & $(1.49)$ & -0.207 & $(1.14)$ & -0.007 & $(0.44)$ \\
\hline Log likelihood & \multicolumn{2}{|c|}{-1610.24} & \multicolumn{2}{|c|}{-1301.36} & \multicolumn{2}{|c|}{-2258.88} \\
\hline
\end{tabular}

Source: LSMS Albania 2003.

Note: (1A), (2A) and (3A) are ordered Probit estimates, (1B), (2B) and (3B) are estimates from a simultaneous model comprising one ordered Probit equation for the financial outcome with endogenous receipt of remittances and one Probit equation for the receipt of remittances. 